\title{
16. Yüzyıl Osmanlı Şeyhülislâmlarından Kemalpaşazâde'ye Dair İlmî-Akademik Literatür ve Değerlendirmesi
}

\author{
Furkan Ramazan ÖĞE*
}

\begin{abstract}
Atıf/Cite as: Öğe, Furkan Ramazan. “16. Yüzyıl Osmanlı Şeyhülislâmlarından Kemalpaşazâde'ye Dair İlmî-Akademik Literatür ve Değerlendirmesi". Recep Tayyip Erdoğan Üniversitesi İlahiyat Fakültesi Dergisi 20 (2021), 321-354.
\end{abstract}

Öz: İslam düşünce geleneğinin Osmanlı dönemi temsilcilerinden Kemalpaşazâde, 15 ve 16. yüzyıllarda yaşamış önemli bir Osmanlı âlimidir. Ona değer katan etkenlerin sayısı çok olsa da en belirgin olanları onun; çok yönlü ilmi kişiliği, sayısı yüzü aşkın eser kaleme alması ve döneminin şeyhülislâmlarından biri olmasıdır. Kemalpaşazâde'nin sahip olduğu değerlerin çokluğu onu, çalışılması ve anlaşılması gereken bir âlim haline getirmiştir. Bu meyanda modern araştırmacılar tarafından Kemalpaşazâde'ye dair çok sayıda eser kaleme alınmıştır. Kemalpaşazâde üzerine yapılan çalışmaların çokluğu da bibliyografik bir çalışmayı gerekli kılmıştır. Zira bir müddet sonra eserlerin tespiti zorlaşmış ve tekrara düşen yayınlar ortaya çıkmaya başlamıştır. Oluşan bu ihtiyacı karşılamak adına Halis Demir ve Kemal Çatılı tarafından “İbn Kemal Üzerine Yapılan İlmi Çalışmalar" başlıklı bir makale yayımlanmıştır. Alandaki boşluğu doldurup araştırmacılara hizmet etse de makaledeki eksikler bu çalışmanın ortaya çıkmasına zemin hazırlamıştır. Söz gelimi Demir ve Çatılı'nın makalesinde tespit edilen çalışma sayısı 198 iken bu makalede tespit edilen sayı -bulunanlara ilaveten- 288'dir. Neticesinde ise Kemalpaşazâde'ye dair tamamlanan toplam araştırma sayısı 486 olmaktadır. Bu kadar çok çalışılan bir isim üzerinde araştırma yapmadan önce yapılmış olanları bilmek ise bir gereklilik arz etmektedir. Bu minvalde makalenin amacı, Kemalpaşazâde'ye ilişkin tamamlanmış çalışmaları tespit edip alanda araştırma yapacakları literatürden haberdar ederek araştırmacılar için bir rehber niteliği taşımak ve nihayetinde ortaya çıkan literatüre dair değerlendirme yapmaktır.

Anahtar Kelimeler: İslam Mezhepleri Tarihi, Osmanlı, Kemalpaşazâde, İbn Kemâl, Literatür, Bibliyografya.

* Arş. Gör., Sakarya Üniversitesi, Sakarya, Türkiye, furkanoge@sakarya.edu.tr, ORCID: www.orcid.org/0000-0002-1236-6072 


\section{Scientific-Academic Literature and Evaluation of Kemalpashazâde a 16th Century Ottoman Shaykh al-Islām}

Abstract: Kamālpashazāde, one of the representatives of the tradition of Islamic thought in the Ottoman period, is an important Ottoman scholar who lived in the 15th and 16th centuries. Many factors add value to him. The most obvious ones are that he was one of the Shaikh al-Islām of his time and a versatile scholar, and wrote more than a hundred works. Since Kamālpashazāde has many values, he has become a scholar that needs to be studied and understood. At this point, many works on Kamālpashazāde have been written by modern researchers. The abundance of studies on Kamālpashazāde also necessitated a bibliographic analysis. Because after a while, it became difficult to identify the works, and repetitive publications began to appear. To meet this need, an article titled "Scientific Studies on Ibn Kamāl" was published by Halis Demir and Kemal Çatıll. Although it fills a gap in the field, the deficiencies in the article have led to the emergence of this study. For example, while the number of studies identified in Demir and Çatıli's paper is 198; the number specified in this article is 288 -in addition to 198-. As a result, the total number of completed studies on Kamālpashazāde is 486 . It is necessary to know what was produced before researching a scholar that has been studied so much. In this context, the article aims to identify the completed studies on Kamālpashazāde, inform researchers who will research in the field about the literature, act as a guide for researchers, and evaluate the current literature.

Keywords: History of Islamic Sects, Ottoman, Kamālpashazāde, Ibn Kamāl, Literature, Bibliography.

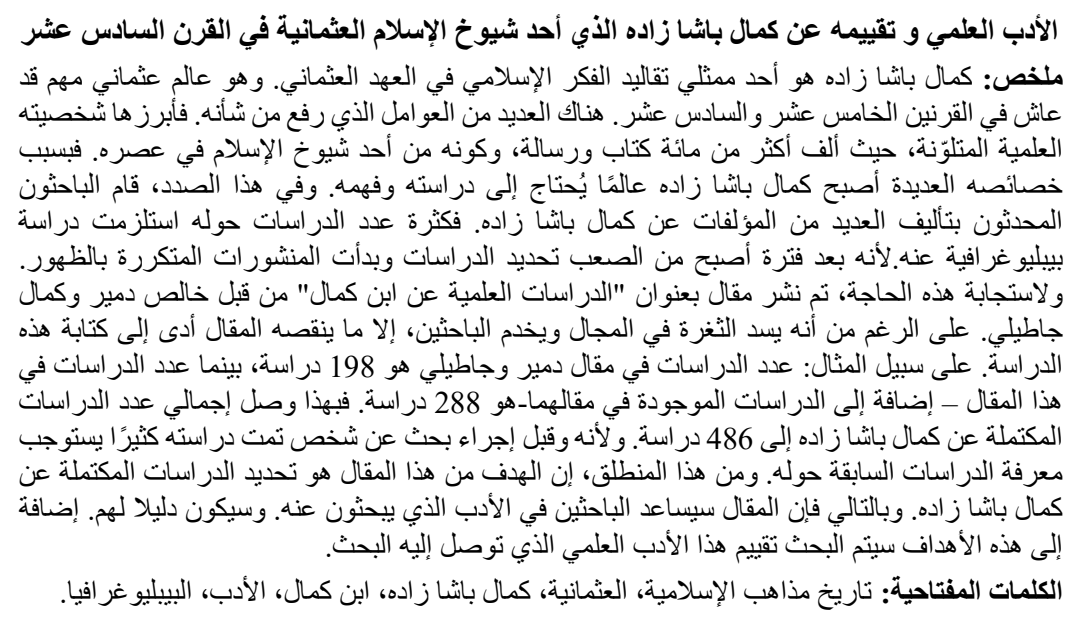

\section{GíRiş}

Velût bir âlim olma özelliğiyle dikkat çeken Kemalpaşazâde, 15 ve 16. yüzyıl Osmanlı'sında yaşamış önemli bir şahsiyettir. Çok yönlü bir âlim olan Kemalpaşazâde, tefsirden hadise, fıkıhtan kelâma, felsefeden edebiyata, belâgatten 
tarihe farklı alanlarda pek çok eser kaleme almıştır. Telif ettiği eserlerin günümüze kadar gelmiş olması ise bizim için bir önemli bir zenginliktir. Modern araştırmacılar bu zenginliğin kıymetini bilmiş ve onu gün yüzüne çıkarmak için büyük çaba sarf etmişlerdir. Makalenin amacı da sarf edilen bu çabayı gözler önüne sermek suretiyle yapılacak yeni çalışmalara katkı sunmaktır.

Kemalpaşazâde'nin yazdığı eserlerin toplam sayısı hakkında farklı görüşler dile getirilmiştir. Bu görüşler arasında en çok tercih edilenler Nihal Atsız ${ }^{1}$, Yekta Saraç ve Şamil Öçal ${ }^{3}$ a aittir. Ancak Kemalpaşazâde'nin eserlerinin listesini verenler bu üç isimle sınırlı değildir. Geçmiş dönemde birçok isim Kemalpaşazâde'nin eserlerinin listesini çıkarmaya yönelik çalışma yapmıştır. Bunlar arasında günümüze yakın en sistemli çalışmalardan biri Muammer Sarıkaya'ya aittir. O, var olan listeleri de göz önüne alarak eserleri dillerine ve alanlarına göre sıralamıştır. ${ }^{4}$ Bununla birlikte Musa Alak tarafından hazırlanan, Kemalpaşazâde'nin basılmış veya üzerinde çalışma yapılmış eserlerini içeren liste de dikkat çekicidir. Alak da bu minvalde 126 eser zikretmiştir. $^{5}$ Kemalpaşazâde'nin eserlerine dair bir başka önemli çalışma ise hiç şüphesiz Mecmû'u resâili'l-allâme İbn Kemâl Bâşâ başlıklı eserdir. ${ }^{6}$ Çalışma, Kemalpaşazâde'nin eserlerinin toplu bir şekilde tahkikini konu edinmektedir. 8 ciltten oluşan eserde 114 risalenin tahkiki yapılmıştır. Bu itibarla eser, Kemalpaşazâde'ye dair yapılan çalışmalar arasında -özellikle ilahiyat disiplinleri söz konusu olduğundaönemli bir yer tutmaktadır.

Kemalpaşazâde Türkçe, Arapça ve Farsça gibi dillerde, farklı bilim dallarında ve muhtelif konular üzerinde pek çok eser telif etmiştir. Onun bu zengin ilmî kişiliğinin yanında şeyhülislâm sıfatını taşıması kendisine gösterilen ilgiyi daha da artırmıştır. Neticede ise yüzü aşkın kıymetli eseriyle çalışılmayı ve anlaşılmayı bekleyen önemli bir Osmanlı âlimi portresi ortaya çıkmıştır.

1 Nihal Atsız Kemalpaşazâde'ye 209 eser nispet etmiştir. bk. Nihal Atsız, "Kemalpaşa-Oğlu'nun Eserleri”, Şarkiyat Mecmuası 6 (1966), 71-112; Nihal Atsı,, “Kemalpaşa-Oğlu'nun Eserleri”. Şarkiyat Mecmuası 7 (1972), 83-135.

2 M. Yekta Saraç, Kemalpaşazâde'nin toplamda 221 eseri olduğunu tespit etmiştir. bk. M. Yekta Saraç, Şeyhülislam Kemal Paşazâde: Hayatı, Şahsiyeti, Eserleri ve Bazı Şiirleri (İstanbul: Risale Yayınları, 1995), 55-73.

3 Şamil Öçal ise Kemalpaşazâde'nin toplamda 226 eseri olduğunu söylemiştir. bk. Şamil Öçal, Kemal Paşazâde'nin Felsefî ve Kelâmî Görüşleri (Ankara: Ankara Üniversitesi, Sosyal Bilimler Enstitüsü, Doktora Tezi, 1998), 9-26.

4 Muammer Sarıkaya, aidiyeti şüpheli olanlarla birlikte Kemalpaşazâde'ye ait toplam 417 eser zikretmiştir. bk. Muammer Sarıkaya, Kemal Paşa-zâde'nin Yabancı Kelimelerin Arapçalaştırılması ve Dil Hataları Konusunda İzlediği Yöntem (İstanbul: İstanbul Üniversitesi, Sosyal Bilimler Enstitüsü, Doktora Tezi, 2004), 328-354.

5 Musa Alak, Kemalpaşazâde'nin Şerhu Tağyîri'l-Miftâh Adlı Eserinin Tahkik ve Tahlili (İstanbul: Marmara Üniversitesi, Sosyal Bilimler Enstitüsü, Doktora Tezi, 2009), 156-181.

6 Ahmed Şemseddin Kemalpaşazâde, Mecmû'u resâili'l-'allâme İbn Kemâl Bâşâ, thk. Hamza el-Bekrî vd. (İstanbul: Dârü'l-Lübâb, 2018). 


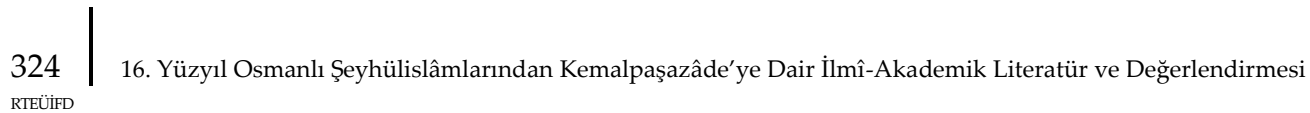

Kemalpaşazâde üzerine yapılan çalışmaların çokluğu, bibliyografik bir çalışma ihtiyacını ortaya çıkarmıştır. Çünkü bir noktadan sonra yapılan çalışmaların tespiti zorlaşmış ve tekrara düşen eserler ortaya çıkmaya başlamıştır. Bu minvalde Halis Demir ve Kemal Çatılı tarafından "İbn Kemal Üzerine Yapılan İlmi Çalışmalar" başlıklı bir makale yayımlanmıştır.7 Mezkûr makale, alandaki büyük boşluğu doldurup araştırmacılara yol göstermiş olmakla birlikte ondaki bazı eksikler, bu çalışmanın yapılmasını gerekli kılmıştır.

Araştırmanın amacı Kemalpaşazâde'ye dair yapılan çalışmaların tam bir listesini vererek literatürü değerlendirmek ve alanda çalışma yapacak araştırmacıları bu literatürden haberdar etmektir. Zira bahsedildiği üzere Kemalpaşazâde çok eser veren bir müellif olduğu kadar çok çalışılan da bir isimdir. Söz gelimi, tespit edildiği kadarıyla bugün için ${ }^{8}$ Kemalpaşazâde üzerine yapılan toplam çalışma sayısı 486 'dır. Bu denli çok çalışılmış bir isme dair araştırma yapmadan mevcut çalışmaları bilmek bir gereklilik arz etmektedir. Makale, araştırmacıya bu bilgiyi vererek onun hem okuma-araştırma aşamasında gerekli kaynaklara ulaşmasını sağlayacak hem de ona hangi çalışmaların yapıldığını gösterecektir. Nitekim literatürü tam bir şekilde görmenin sağladığı katkının yanında araştırmacıları tekrara düşmekten korumak da makalenin hedeflerinden biridir. Çünkü literatür incelendiğinde, mevcut yayınlardan habersiz olarak yapılmış benzer araştırmalar görülmektedir. Bununla beraber Kemalpaşazâde, yalnızca geçmişte çalışılan değil, bilakis hala da çalışılmakta olan bir isimdir. Halihazırda İSAM veritabanındaki bilgilere göre Kemalpaşazâde üzerine iki doktora beş de yüksek lisans çalışması yürütülmektedir. Ayrıca önümüzdeki yıl Ankara'da 13-15 Mayıs 2022 tarihlerinde “Uluslararası Kemalpaşazâde (İbn Kemal) Sempozyumu" gerçekleştirilecektir.

Makalede Kemalpaşazâde'ye dair yapılan çalışmalar belirli başlıklar altında listelenmiştir. Var olan literatürün tespiti ise pek çok veritabanının titizlikle taranmasıyla gerçekleştirilmiştir. Bu veritabanlarından meşhur birkaçı şunlardır: JSTOR, EBSCO tarafından sağlanan veritabanları, Open Dissertations, ProQuest, Sobiad, Scopus, SpringerLink, Web of Science, TR Dizin, İSAM veritabanları, DergiPark, Google Scholar, Dar Almandumah, Hathi Trust, YÖK Ulusal Tez Merkezi vb. Buna ilaveten yazılan kitapların, yürütülen tezlerin ve yapılan makalelerin kaynakça kısımları da taranarak literatür son haline getirilmiştir. Çalışma hazırlanırken dikkat edilen hususlardan biri de hata payını asgariye düşürebilmek için yapılan çalışmalara ilk eden ulaşmak olmuştur.

7 Halis Demir - Kemal Çatılı, "İbn Kemal Üzerine Yapılan İlmi Çalışmalar”, Tokat Gaziosmanpaşa Üniversitesi Illahiyat Fakültesi Dergisi 7/1 (2019), 151-178.

82021 Eylül'ü itibariyle. 
Çalışmanın Halis Demir ve Kemal Çatılı tarafından telif edilen literatür makalesiyle olan ilişkisi ise şöyledir: Öncelikle bizim çalışmamızda diğer makalede bulunan çalışmalara yer verilmemiştir. Makalenin hacmini faydasız artıracağından dolayı bu tutumdan kaçınılmıştır. O nedenle araştırmacılardan literatürün tümüne ulaşmak için iki makaleyi birlikte ele alması beklenmektedir. Bu itibarla çalışma, akademik bir zeyl olarak da düşünülebilir. İlaveten, diğer makalede tespit edilen bazı küçük hatalara zikre değer olmadıkları için çalışma içerisinde işaret edilmemiştir. İki çalışma arasındaki detaylara dair şunlar söylenebilir; Demir ve Çatılı'nın makalesinde bulunan bir kitap, farklı bir yayınevinden tekrar basıldıysa o eser çalışmaya dahil edilmiştir. Benzer bir örnek olarak; Ahmet Uğur, Kemalpaşazâde'nin Tevârîhi Âl-i Osman'ının 8. cildini dört kısım halinde belirli aralıklarla makale şeklinde Ankara Üniversitesi İlahiyat Fakültesi Dergisi'nde yayımlamıştır. En son yayınından on yıl sonra da bu çalışma Türk Tarih Kurumu'nda kitap olarak basılmıştır. Demir ve Çatılı, makalelerinde yalnızca kitabı zikrederken bu çalışmada -hem kitabın arka planını oluşturmaları hem de yayımlanmış olmaları gerekçesiyle- makalelere de yer verilmiştir. Başka bir örnek olarak bir yazar aynı makaleyi farklı dergilerde yayımladıysa ve Demir'le Çatılı'nın makalesinde bunlardan yalnızca biri bulunuyorsa -yine yayımlanmış olması hasebiyle- yazarın diğer makalesi de listeye alınmıştır. Burada amaç, literatürü eksiksiz bir şekilde ortaya koymaktır. Ancak hemen belirtilmelidir ki yukarıda sözü edilen durumlar istisna teşkil etmektedir.

İki çalışma arasındaki sayısal değerler söz konusu olduğunda; Demir ve Çatılı'nın makalesinde yer alan eser sayısı 198 iken bu makaledeki sayı 288'dir. Ancak fazlalığın bir kısmının Demir ile Çatılı'dan sonra yayımlanan çalışmalardan kaynaklandığı da ifade edilmelidir. Söz gelimi 2021 yılında 14, 2020 yılında 16 çalışma yapılmıştır. Bununla birlikte her ne kadar makale, 2019 yılının Haziran'ında yayımlanmış olsa da bu yıldaki çalışmalar da makale sonrası çalışmalar olarak değerlendirilebilir ki bunların sayısı da 27'dir. Buna göre araştırmada eksik 231 çalışmanın tespit edildiği söylenebilir.

Oluşturulan literatür öncelikle dillerine göre ayrılıp Türkçe, Arapça ve diğer yabancı diller şeklinde üç başlık altına yerleştirilmiştir. Nihai olarak makaledeki çalışmaların, yıllarına göre alfabetik sırayla listelendiği söylendikten sonra literatüre geçilebilir.

\section{Türkçe Çalışmalar}

Türkçe çalışmalar başlığında ilk sırada belirli bir konuya hasredilmiş ve uzun yıllar çalışılmış olması sebebiyle doktora tezleri yer almıştır. Ardından tez kategorisinden devam etmek amacıyla yüksek lisans tezlerine yer verilmiştir. Yüksek lisans tezlerini, telif edilmiş kitap çalışmaları takip etmiş, kitapları takiben de makaleler listelenmiştir. Kitap bölümleri sayıca az bir yekûn tuttuğu için makale 


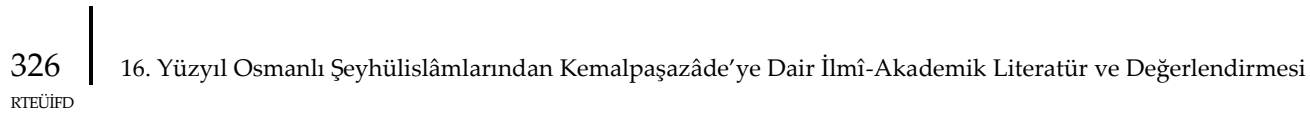

olarak mütalaa edilmiştir. Makale sonrasında, basılan tebliğ metinlerine ve ardından neşir ve tahkik çalışmalarına yer verilmiştir. Ancak bu kısımda eserlerin matbu olması temel kriter olmuştur. Zira pek çok yüksek lisans, doktora ve makale çalışması da tahkik hüviyetini taşımaktadır. Başlık altındaki son kısım ise ansiklopedi maddelerine ayrılmıştır.

\subsection{Doktora Tezleri}

Severcan, Şerafettin. Kemal Paşa-zâde Tevarih-i Âl-i Osman: 10. Defter. Erciyes: Erciyes Üniversitesi, Sosyal Bilimler Enstitüsü, Doktora Tezi, 1991.

Çiçekler, Mustafa. Kemal Paşa-zâde ve Nigâristân'ı. İstanbul: İstanbul Üniversitesi, Sosyal Bilimler Enstitüsü, Doktora Tezi, 1994.

Ege, Ramazan. İbn Kemâl'in Esrâru'n-Nahvi ve Dönemindeki Arap Dili Filolojik Çalışmalarına Kısa Bir Bakış. İzmir: Dokuz Eylül Üniversitesi, Sosyal Bilimler Enstitüsü, Doktora Tezi, 2002.

Sarıkaya, Muammer. Kemal Paşa-zâde'nin Yabancı Kelimelerin Arapçalaştırılması ve Dil Hataları Konusunda İzlediği Yöntem. İstanbul: İstanbul Üniversitesi, Sosyal Bilimler Enstitüsü, Doktora Tezi, 2004.

Kaçar, Mücahit. İbn Kemâl Dîvânı'nın İncelenmesi: (Nazım Bilgisi - Belâgat - Üslûp ve Dil Özellikleri - Muhtevâ). İstanbul: İstanbul Üniversitesi, Sosyal Bilimler Enstitüsü, Doktora Tezi, 2010.

\subsection{Yüksek Lisans Tezleri}

Konur, Himmet. Kemal Paşa-Zade'nin Kaside-i Hamriye Şerhi (Edisyon, Kritik ve Tahlil). İzmir: Dokuz Eylül Üniversitesi, Sosyal Bilimler Enstitüsü, Yüksek Lisans Tezi, 1992.

Yılmaz, Abdulkadir. Kemâl Paşa-zâde ve Sarfi: Metin ve İnceleme. Erzurum: Atatürk Üniversitesi, Sosyal Bilimler Enstitüsü, Yüksek Lisans Tezi, 1992.

Günaydın, Yusuf Turan. İbn-i Kemal, Edebi Kişiliği ve Kaside-i Bürde Tercümesi (Tenkitli Metin). Ankara: Ankara Üniversitesi, Sosyal Bilimler Enstitüsü, Yüksek Lisans Tezi, 1995.

Polat, Mahmut. Kemal Paşazâde'nin el-Kasîdetü'l-Hamriyyesi'nin Edisyon Kritiği. Şanlıurfa: Harran Üniversitesi, Sosyal Bilimler Enstitüsü, Yüksek Lisans Tezi, 1995.

Çelik, Gülderen. İbn-i Kemâl Divânı'nda İnsan Unsuru. Eskişehir: Eskişehir Osmangazi Üniversitesi, Sosyal Bilimler Enstitüsü, Yüksek Lisans Tezi, 2005.

Yıldırım, Muhammed Atıf. Birgivî'nin Şeyhayn (Burhânüşşerîa ve Sadrüşşerîa) Savunması (Risâle fi reddi'l-Islâh ve'l-îzâh). İstanbul: Marmara Üniversitesi, Sosyal Bilimler Enstitüsü, Yüksek Lisans Tezi, 2009. 
Cesur, Ahmet. Kemalpaşazâde'nin Risâle fi Tekaddümi'l-Illeti't-Tâmme 'Ale'l-Ma'lûl Adlı Eserinin Tahkik, Tercüme ve Değerlendirmesi. Sakarya: Sakarya Üniversitesi, Sosyal Bilimler Enstitüsü, Yüksek Lisans Tezi, 2011.

Özdemir, Sümeyye. Zürrî Vakıflarda Kullanılan "Çocukların Çocukları" Lafzının Vâkıfın Kızının Çocuklarını Kapsaması (Hatipzâde, Kemalpaşazâde ve İbn Nüceym'in Risaleleri Bağlamında). İstanbul: Marmara Üniversitesi, Sosyal Bilimler Enstitüsü, Yüksek Lisans Tezi, 2011.

Yıldız, Yasemin. Kemâlpaşazâde'nin "Ziyâdetü'l-Vücûd 'Ale'l-Mâhiyye" Adlı Risâlesinin Tahkik ve Değerlendirilmesi. Sakarya: Sakarya Üniversitesi, Sosyal Bilimler Enstitüsü, Yüksek Lisans Tezi, 2012.

Halıc1, Mete. Türk Edebiyatındaki Yusuf u Züleyha Mesnevilerinde Anlatılan Konuların Kaynakları. Nevşehir: Nevşehir Üniversitesi, Sosyal Bilimler Enstitüsü, Yüksek Lisans Tezi, 2013.

Aktaş, Mehmet. Kemalpaşazâde'nin Zihnî Varlık Risâlesi: Tahkîk ve Değerlendirme. İstanbul: Marmara Üniversitesi, Sosyal Bilimler Enstitüsü, Yüksek Lisans Tezi, 2014.

Topcu, Mustafa. Kemalpaşazâde'nin Safvetü'l-Menkûlât fî şerhi Şurûtı's-Salât İsimli Eserinin Edisyon Kritiği ve Değerlendirilmesi. Konya: Necmettin Erbakan Üniversitesi, Sosyal Bilimler Enstitüsü, Yüksek Lisans Tezi, 2017.

Uzunyol, Muhammed. Kemâl Paşazâde'de (873/1469-940/1534) Tasavouf ve Risâletü'l-Münîre İsimli Eseri Bă̆lamında İlim ve İş̧âd. Isparta: Süleyman Demirel Üniversitesi, Sosyal Bilimler Enstitüsü, Yüksek Lisans Tezi, 2017.

İlbaylı, Şeyma. Osmanlı Devleti XVI. Yüzyıl Kelamcıları - İbn Kemâl, Taşköprülüzâde ve Birgivî Örneği-. Gaziantep: Gaziantep Üniversitesi, Sosyal Bilimler Enstitüsü, Yüksek Lisans Tezi, 2018.

Yılmaz, Hakan. İbn Kemâl (Kemâl Paşa-Zâde): Tārīh-i İbn Kemāl / VI. Defter (İnceleme - Transkripsiyon - Tıpkıbasım). Sakarya: Sakarya Üniversitesi, Sosyal Bilimler Enstitüsü, Yüksek Lisans Tezi, 2018.

Yılmaz, Halil İbrahim. Kemâlpaşazâde'nin Esrâru'n-Nahv'i ile Birgivî'nin İzhâru'lEsrâr'ının Mukâyesesi. İstanbul: Fatih Sultan Mehmet Vakıf Üniversitesi, Sosyal Bilimler Enstitüsü, Yüksek Lisans Tezi, 2018.

Bahçeci, Rabia Hacer. İbn Kemal Tefsirinin el-Keşşâf Geleneğindeki Yeri: Dil ve Belâgat İlimleri Çerçevesinde Mukayeseli Bir İnceleme. İstanbul: İstanbul 29 Mays Üniversitesi, Sosyal Bilimler Enstitüsü, Yüksek Lisans Tezi, 2019.

Çıtır, Mücahit. İbn Kemal ve Rafıza'ya Bakışı. Yozgat: Yozgat Bozok Üniversitesi, Sosyal Bilimler Enstitüsü, Yüksek Lisans Tezi, 2019. 


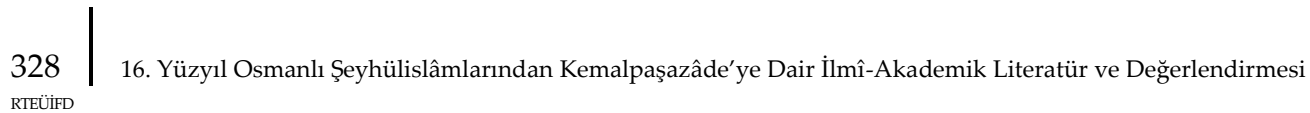

Kara, Yusuf. İbn Kemal Paşa'nın el-Islah Adlı Eserinde el-Vikaye'ye Yönelttiği Eleştirilerin Değgerlendirilmesi. İstanbul: Marmara Üniversitesi, Sosyal Bilimler Enstitüsü, Yüksek Lisans Tezi, 2019.

Memük, Yusuf. Taşköprîzâde'nin Kemalpaşazâde'ye Yönelttiği Eleştiriler: Hâş̧iye 'Alâ Şerhi'l-Keşşâf li'l-Cürcân̂̂ Bă̆lamında. İstanbul: Marmara Üniversitesi, Sosyal Bilimler Enstitüsü, Yüksek Lisans Tezi, 2019.

Mergen, Faruk. İbn Kemal Paşa'nın "Risâle li Hakkı'z-Zenâdıka" Adlı Eseri Bağlamında Râfıza ve Zındıklara İlişkin Görüşleri. İstanbul: Marmara Üniversitesi, Sosyal Bilimler Enstitüsü, Yüksek Lisans Tezi, 2019.

Öztürk, İsa. Kemalpaşazâde'nin Sadruşşerîa'ya Yönelttiŏi Eleştirilerin Tespit ve Tahlili (el-Îzâh ve şerhu'l-Vikâye Bağlamında). Çorum: Hitit Üniversitesi, Sosyal Bilimler Enstitüsü, Yüksek Lisans Tezi, 2019.

Yolcu, Ahmet Faruk. İmkân Risaleleri Bağlamında Kemalpaşazâde'nin İmkân Anlayışı. Sakarya: Sakarya Üniversitesi, Sosyal Bilimler Enstitüsü, Yüksek Lisans Tezi, 2019.

Gün, Rabia. Kemalpaşazâde'nin Şerhu Risâleti İsbâti'l-Vâcib Adlı Eserinin Tahkik ve Incelemesi. Isparta: Süleyman Demirel Üniversitesi, Sosyal Bilimler Enstitüsü, Yüksek Lisans Tezi, 2020.

Saraç, Ahmet Selman. Şeyhülislam Kemal Paşazâde'nin "Şerhu Tağyîri't-Tenkîh" İsimli Eserinin "et-Taksîmü's-Sânı̂"ye Kadar Olan Kısmının Tahkîki. İstanbul: Marmara Üniversitesi, Sosyal Bilimler Enstitüsü, Yüksek Lisans Tezi, 2020.

Saygan, Çağlar. Kemâlpâş̧âzâde'nin Tevârîh-i Âl-i Osmân Adlı Eserinin VI. Defterinin Transkripsiyonu. Muğla: Muğla Sıtkı Koçman Üniversitesi, Sosyal Bilimler Enstitüsü, Yüksek Lisans Tezi, 2020.

Tan, Taha Yasin. Hanefî Furû Literatüründe Uyuşturucu Maddelerin Hükmü: İbn Kemal ve Ebussuud'un Afyon, Benc ve Haşiş Hakkındaki İhtilafları Örnekliğinde Bir Inceleme. İstanbul: Marmara Üniversitesi, Sosyal Bilimler Enstitüsü, Yüksek Lisans Tezi, 2020.

\subsection{Kitaplar}

Kılıçl1, Mustafa. Atatürk Üniversitesi Merkez Kütüphanesinde Kemal Paşa-Zâde'nin Eserlerine Ait Yazmalar. Erzurum: Atatürk Üniversitesi Fen-Edebiyat Fakültesi Ofset Tesisleri, 1992.

Saraç, M. Ali Yekta. Şeyhülislâm Kemalpaşazâde. İstanbul: Şule Yayınları, 1999.

Alper, Ömer Mahir. Varlık ve İnsan: Kemalpaşazâde Bă̆lamında Bir Tasavvurun Yeniden İnşası. İstanbul: Klasik Yayınları, 2010. 
İnanır, Ahmet. Şeyhülislâm İbn Kemal'in Fetvaları Işı̆̆ında Kanûn̂ิ Devrinde Osmanlı'da Hukukî Hayat: Mes'eleler ve Çözümleri (Fetâvâ-yı İbn Kemal). İstanbul: Osmanlı Araştırmaları Vakfı, 2011.

Kemalpaşazade, İbn Kemal Ahmed Şemseddin. Aydınlatıcı Risale: Bir Dönem Osmanlıya Yön Veren Alim. çev. Nevzat Bakır. İstanbul: Milsan Basın, 2013.

Öçal, Şamil. Kışladan Medreseye: Osmanlı Bilgini Kemalpaşazâde'nin Düşünce Dünyası. İstanbul: İz Yayıncılık, 2013.

Aydın, Mehmet. İbn Kemal Paşa ve Taşköprülüzâde'de Zihnî Varlık. Ankara: Illâhiyât Yayınları, 2016.

Biçer, Ramazan. Kemalpaşazâde. İstanbul: İlke Yayıncılık, 2016.

Derin, Necmi. Kemal Paşazade ve Taşköprizade Risaleleri Bağlamında İslam Düşüncesinde Zihni Varlık Problemi. Ankara: İlâhiyât Yayınları, 2016.

Ege, Ramazan. İbn Kemâl'in Def'u mâ yete'allak bi'z-zamâir mine'l-evhâm Adlı Risâlesi (Arap Dilinde Zamir): Tahkik, Talik ve Tercüme. Kayseri: Tiydem Yayıncıllk, 2017.

Atsız, Hüseyin Nihal. İstanbul Kütüphanelerine Göre Dört Bibliyografya. İstanbul: Ötüken Neşriyat, 2018.

Dalkıran, Sayın. İbn-i Kemâl'e Göre Ehl-i Sünnet Düşüncesi. İstanbul: Osmanlı Araştırmaları Vakfı, 2018.

Işık, Harun. İnsanların ve Cinlerin Müftüsü İbn Kemal. İstanbul: Erdem Yayınları, 2018.

Muradoğlu, Hızır Ali. Şeyhülislâm Kemâl Paşazâde: Hayatı, Şahsiyeti, Eserleri ve Risâle fî Beyân Ahvâl ez-Zamâir. İstanbul: Kökler Kitabevi, 2019.

Bayraktutar, Muammer. İbn Kemâl'in Hadis Şerhi Risâleleri. Ankara: İlâhiyât Yayınları, 2020.

Koca, Ferhat. Kemalpaşazâde'ye Göre Insanın Varlık Yapısı İnsanî Şahsiyet. Ankara: Araştırma Yayınları, 2020.

\subsection{Makaleler}

Pertev, Ethem. “Medh-i Sa'y ve Zemm-i Betâlet Hakkında Meşâhîr-i Ulemâ-yı İslâmiyeden Kemal Paşazâde'nin Arabî Risâlesi Tercemesi". Mecmua-i Fünun 32 (1281/1865), 281-289.

Turan, Şerafettin. “İbn-i Kemâl'in Kanûnî Süleyman'a Bir Mektubu". Tarih Vesikaları Yeni Seri 2/17 (1958), 221-223.

Altınay, Ahmed Refik. "Osmanlı Şeyhülislâmlarının Terâcim-i Ahvâli: İbn-i Kemal Ahmed Şemsüddin Efendi”. Diyanet İşleri Başkanlı̆̆ı Dergisi 3/5 (1964), 154. 


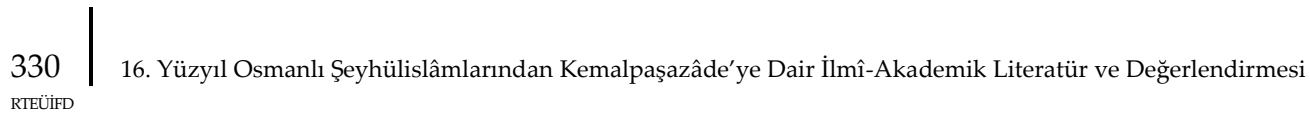

Refik, Ahmed. "Osmanlı Şeyhülislâmlarının Terâcim-i Ahvâli: İbn-i Kemal Ahmed Şemsü'd-din Efendi". Diyanet İşleri Başkanlığı Dergisi 4/1-2 (1965), 92.

Tekindağ, M. C. Şehabeddin. “Yeni Kaynak ve Vesîkaların Işığı Altında Yavuz Sultan Selim'in İran Seferi". İstanbul Üniversitesi Edebiyat Fakültesi Tarih Dergisi 17/22 (1967), 49-78.

Levend, Agâh Sirrı. "Kemal Paşa-zade'nin Yusuf u Züleyha'sı". Türk Dili Araştırmaları Yıllı̆̆ı - Belleten 17 (1969), 251-281.

Atsız, Nihal. “Kemalpaşa-Oğlu'nun Eserleri”. Şarkiyat Mecmuası 7 (1972), 83-135.

Küçükibrahimoğlu, Osman Nuri. “İbn Kemal Paşa”. Diyanet İşleri Başkanliğı Dergisi 11/2 (1972), 115-118.

Kılıçer, M. Esad. “Kemâlpaşazade'nin Âile Hukuku ile İlgili Bazı Fetvaları”. Ankara Üniversitesi İlahiyat Fakültesi Dergisi 19 (1973), 83-95.

Ayverdi, Ekrem Hakkı. “Müftiyyü's-Sakaleyn”. Kubbealtı Akademi Mecmuası 4/3 (1975), 24-31.

Kemalpaşazade, İbn Kemal Ahmed Şemseddin. "Risâle-i Münire (İslam Güneşi)". Vesîletü'n-Necât: Seâdet Yolu. haz. A. Faruk Meyan - Abdürreşid Avanoğlu. 10-80. İstanbul: Berekat Yayınları, 2. Basım, 1977.

Uğur, Ahmet. “Dresden'de Kemal Paşa-Zade'ye Atfedilen Yazma Eserler". Ankara Üniversitesi İlahiyat Fakültesi Dergisi 3 (1977), 314-343.

Uğur, Ahmet. “Kemal Paşa-Zade'nin VIII. Defteri (Kısım 2)”. Ankara Üniversitesi İlahiyat Fakültesi Dergisi 27 (1985), 265-280.

Uğur, Ahmet. "Kemal Paşa-Zade'nin VIII. Defteri". Ankara Üniversitesi İlahiyat Fakültesi Dergisi 28 (1986), 269-289.

Uğur, Ahmet. “Kemal Paşa-Zade'nin VIII. Defteri (3)". Erciyes Üniversitesi İlahiyat Fakültesi Dergisi 3 (1986), 89-110.

Uğur, Ahmet. “Kemal Paşa-Zade'nin VIII. Defteri (Devamı)". Ankara Üniversitesi İlahiyat Fakültesi Dergisi 29 (1987), 223-240.

Uğur, Ahmet. "Kemal Paşa-Zade ve Şah İsmail (Safavîler)”. Erciyes Üniversitesi İlahiyat Fakültesi Dergisi 4 (1987), 13-28.

Uğur, Ahmet. "Kemal Paşa-Zade ve Yavuz Sultan Selim". Erciyes Üniversitesi Sosyal Bilimler Enstitüsü Dergisi 1 (1987), 1-14.

Ocak, Ahmet Yaşar. “İbn Kemal'in Yaşadığı XV ve XVI. Asırlar Türkiye'sinde İlim ve Fikir Hayatı”. Din Öğretimi Dergisi 32 (1992), 65-71. 
Özcan, Bekir. "İnsana Verdiği Önem Yönünden İbn Kemal'in Nigâristân'1". Dokuz Eylül Üniversitesi İlahiyat Fakültesi Dergisi 7 (1992), 243-256.

Dalkıran, Sayın. "İbn-i Kemal'in Tilsımât Risâlesi”. Türk Dünyası Araştırmaları 104 (1996), 195-208.

Dalkıran, Sayın. “İrşâdü'l-Mütehayyirîn”. Türk Dünyası Araştırmaları 109 (1997), 111-122.

Develi, Hayati. "Kemalpaşazade ve Ebüssuûd'un Galatât Defterleri". İlmi Araştırmalar 4 (1997), 99-125.

Saraç, M. A. Yekta - Çiçekler, Mustafa. “Kemalpaşazâde'nin Kâfiye Risâlesi”. İstanbul Üniversitesi Edebiyat Fakültesi Türk Dili ve Edebiyatı Dergisi 28 (1998), 445-477.

Arslan, Fikret. "Kemâl Paşa-Zâde ve Eserleri". Selçuk Üniversitesi Fen-Edebiyat Fakültesi Edebiyat Dergisi 14 (2002), 161-180.

Gürer, Dilâver. "Semâ ve Devrân Hakkında İki Risale". Marife: Dini Araştırmalar Dergisi 3/1 (2003), 255-260.

Demirel, Mustafa. "Kemâl Paşazâde ve Yûsuf u Zeliha'sı". Türk Dünyası Araştırmaları 154 (2005), 209-238.

El-'Ubeydî, Reşîd Abdurrahmân. "İbn Kemâl Paşa'nın Arap Dilindeki Çalışmaları". çev. Ahmet Yüksel. Din Bilimleri Akademik Araştırma Dergisi 5/1 (2005), 261-277.

Erdem, H. Sabri. “Türk Kelâmciları İbn Kemâl (1468-1534) ve Mustafa Sabri’de (1860-1954) Kader Problemi ve Anlambilim Açısından Bir Değerlendirme". Ankara Üniversitesi İlahiyat Fakültesi Dergisi 46/2 (2005), 43-54.

Yavuz, Salih Sabri. "Kelâm'da Efdaliyyet Meselesi ve İbn Kemal'in “Efdaliyyetu Muhammed" Risalesi". Din Bilimleri Akademik Araştırma Dergisi 5/1 (2005), 147-184.

Ceyhan, Âdem. "Şeyhülislâm Kemalpaşazâde'ye Mâl Edilen Bazı Şiirler". Edebiyat Otağı 4 (2006), 11-19.

Köksal, Fatih. “İbni Kemâl Dîvânı'nın Neşri Üzerine Tespitler”. Türklük Araştırmaları 23 (2008), 145-180.

Özer, Hasan. “İbn-i Kemâl ve Tabakâtü'l-Fukahâ Adlı Eseri”. İslam Araştırmaları Dergisi 14 (2009), 353-374.

Tan, Muzaffer. “Geç Dönem Hanefî-Mâturîdî Fırak Geleneği Bağlamında Bir Risâle: el-Makâlât fî Beyâni Ehli'l-Bida' ve'd-Dalâlât". Fırak Üniversitesi İlahiyat Fakültesi Dergisi 14/1 (2009), 181-202. 
\begin{tabular}{l|l}
332 & 16. Yüzyıl Osmanlı Şeyhülislâmlarından Kemalpaşazâde'ye Dair İlmî-Akademik Literatür ve Değerlendirmesi \\
RTEÜFD &
\end{tabular}

Gürer, Dilaver. “Osmanlılar'da Semâ, Devrân, Raks Tartışmaları ve İki Şeyhülislâm Risâlesi". Tasavouf İlmi ve Akademik Araştırma Dergisi 11/26 (2010), 1-23.

Öge, Ali. "Şeyhülislam İbn Kemal'in Fetvaları Işığında Osmanlı İktisâdî Hayatından Bir Kesit”. İslam Hukuku Araştırmaları Dergisi 16 (2010), 275-298.

Özer, Hasan. "İbn-i Kemâl ve "Riba” Adlı Risalesi”. İslam Hukuku Araştırmaları Dergisi 16 (2010), 157-186.

Aydın, Abdullah. “İbn Kemâl'in Bir Gazelinin Şerhi ve Ses Tekrarları Açısından Değerlendirilmesi". Sosyal Bilimler Araştırmaları Dergisi 7/2 (2012), 13-28.

Erdem, Engin - Necmettin, Pehlivan. "Varlığın ve Yokluğun Ötesi: Kemalpaşazade'nin “Leys ve Eys'in Anlamının İncelenmesine Dair Risale"si”. İslam Araştırmaları Dergisi 27 (2012), 87-116.

Özdemir, Hakan. “Günümüze Göre Klasik Türk Edebiyatındaki Eskicil Unsurlar, İbn-i Kemâl Örneği". Turkish Studies 7/4 (2012), 2501-2509.

İnanır, Ahmet. "XVI. Yüzyıl Osmanlı Fakih ve Sûfîlerin Semâ, Raks ve Devrân Tartışmalarında Lehte ve Aleyhte Kullandıkları Hukûki Deliller ve Değerlendirilmesi". Cumhuriyet Üniversitesi İlahiyat Fakültesi Dergisi 17/2 (2013), 237-269.

Turgut, Kadir. “Kemalpaşazâde'nin Hâfız'a Ait Bir Beytin Şerhini İçeren Farsça Risalesi”. Doğu Araştırmaları Dergisi 11 (2013), 25-48.

Sözen, Kemal. “İbn Kemal'in Tehâfüt Geleneğindeki Yeri ve Önemi”. Dört Öge 5 (2014), 115-125.

Toksöz, Hatice. "Kemalpaşazâde'nin Risâle Muallaka Alâ Şerhi'1-İşârât ve'1Muhâkemât Eseri Üzerine Bir Değerlendirme”. Dört Öge 6 (2014), 23-32.

Alper, Ömer Mahir. “Mahiyetin Mec'ûliyeti Bağlamında Kemalpaşazâde'nin Cürcânî Eleştirisi”. İslam Düşüncesinde Süreklilik ve Değişim Seyyid Şerif Cürcânî Örneği ed. M. Cüneyt Kaya. 197-224. İstanbul: Klasik Yayınları, 2015.

Bayer, İsmail. “Kemal Paşazade'nin fî Fadîleti'l-Lisâni'l-Fârisî Adlı Risalesinde Fars Diline Ait Görüşleri". Mütefekkir Aksaray Üniversitesi İslami İlimler Fakültesi Dergisi 2/3 (2015), 177-181.

Kemalpaşazâde. “Aklın İzahına Dair". çev. Ömer Mahir Alper. Osmanlı Felsefesi Seçme Metinler. ed. Ömer Mahir Alper. 217-233. İstanbul: Klasik Yayınları, 2015.

Kemalpaşazâde. “İnsanın Varlık Yapısına Dair”. çev. Ömer Mahir Alper. Osmanl Felsefesi Seçme Metinler. ed. Ömer Mahir Alper. 211-215. İstanbul: Klasik Yayınları, 2015. 
Kemalpaşazâde. "Mümkün Bir Kadîm Varlığın Müessire Dayanmasının İmkânına Dair Bir İnceleme". çev. Ömer Mahir Alper. Osmanlı Felsefesi Seçme Metinler. ed. Ömer Mahir Alper. 199-210. İstanbul: Klasik Yayınları, 2015.

Kemalpaşazâde. "Yaratmanın (Ca'l) Anlamının Açıklanması ve Mahiyetin Yaratılmış (Mec'ul) Olup Olmadığının İncelenmesine Dair". çev. Ömer Mahir Alper. Osmanlı Felsefesi Seçme Metinler. ed. Ömer Mahir Alper. 169-197. İstanbul: Klasik Yayınları, 2015.

Koca, Ferhat. “Kemalpaşazâde'nin Risâle fi'ş-Şahsı'l-İnsânî Adlı Eseri ve Osmanlıca Tercümeleri" Hitit Üniversitesi Illahiyat Fakültesi Dergisi 15/29 (2016), 5-32.

Kaya, Erdal. "Kemalpaşazâde'nin "Risale fî İ'câzi'l-Kur'ân” Adlı Risalesi: İnceleme ve Tahkik". Akademik-Us: Artvin Çoruh Üniversitesi İlahiyat Araştırmaları Dergisi 1/2 (2017), 245-267.

Sarı, Hacı - Erdoğmuş, Nihat. “Kemalpaşazade'nin “fi'l-Hassi ‘ala's-Sa yi ve'lMen'i 'ani'l-Betâle" Adlı Risalesi Çerçevesinde İslam Emek Tasavvuru Üzerine Bir Deneme". İş Ahlakı Dergisi 11/2 (2018), 377-390.

Tanyıldız, Ahmet - Şahin, Oğuzhan. “Kemâl Paşazâde'nin Farsçadaki Yâ Harfine Dair Bir Eseri: Yâiyye Risâlesi”. Hikmet - Akademik Edebiyat Dergisi (2018), 336-370.

Yolcu, Ahmet Faruk. "İmkânın Ezelîliği ve Ezelîliğin İmkânı Sorununda Kemalpaşazâde'nin Cürcânî Eleştirisi”. Kocaeli Üniversitesi İlahiyat Fakültesi Dergisi 2/2 (2018), 80-95.

Aktan, Muhammed Felat - Biner, Fuat. "Kemalpaşazâde'nin 'Gelür Gider' Redifli Gazelinin Şerhi”. Dicle Üniversitesi Sosyal Bilimler Enstitüsü Dergisi 12/23 (2019), 128-134.

Alper, Ömer Mahir - Apaydın, Yasin. “Kemalpaşazâde'nin Tecrîd Eleştirisi ve Yeniden İnşası Olarak Tecvîdü't-Tecrîd: İnceleme ve Tenkitli Neşir". Nazariyat: İslâm Felsefe ve Bilim Tarihi Araştırmaları Dergisi 5/1 (2019), 81/131.

Ayçiçeği, Bünyamin. “İbn Kemâl'in Yavuz Mersiyesi ve Tahir Olgun'un Şerhi”. Türk Kültürü Incelemeleri Dergisi 40 (2019), 417-450.

Demir, Halis - Çatılı, Kemal. "İbn Kemal Üzerine Yapılan İlmi Çalışmalar". Gaziosmanpaşa Üniversitesi İlahiyat Fakültesi Dergisi 7/1 (2019), 151-178.

Demir, Osman. “Basit ve Bileşik: Kelâmda Cismin Tanımı ve İbn Kemâl'in Tafra Eleştirisi”. Kader 17/1 (2019), 15-35. 


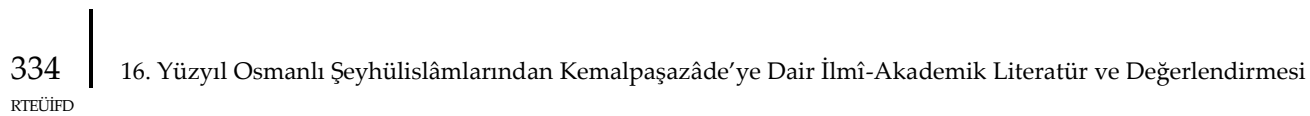

İnce, Muhammed. “Reddiyenin Türk Şerh Edebiyatındaki Gelişimi ve İbnü'1Kemâl'in Mollâ Câmî’ye Reddiyesi". Hacettepe Üniversitesi Türkiyat Araştırmaları Dergisi 30 (2019), 127-142.

Kaçar, Mücahit. “Kemal Paşa-zâde'nin Şiirlerinin Aruz, Kafiye ve Üslup Hususiyetleri". Artuklu Insan ve Toplum Bilim Dergisi 4/1 (2019), 16-25.

Pehlivan, Necmettin - Çelik, Muhammet. "el-Mațlabul-E' lā, el-Maḳșadu'l-Aḳsā: Kemālpāşāzāde'nin Risāle fāi 'ilmi Ādābi'l-Bahșśn'”. Bingöl Üniversitesi Sosyal Bilimler Enstitüsü Dergisi 9 (2019), 363-390.

Yavuz, Engin - Büyük, Köksal. “İbn-i Kemal'de Yönetim Düşüncesi”. Stratejik Yönetim Araştırmaları Dergisi 2/2 (2019), 165-183.

Yıldız, Kemal - Rüveyda, Yıldız. "Tâceddin el-Asğâr İbrahim b. Abdullah elHamîdî'nin "Hâşiyetün ale'l-Islâh ve'l-Îzâh li İbn-i Kemalpaşa” Adlı Haşiyesinin Neşri, Tercümesi ve Değerlendirilmesi (Kemalpaşazâde'nin "İzâhu'l-Islâh" Adlı Eserine Yazılan Bir Reddiye Örneği)". Recep Tayyip Erdoğan İlahiyat Fakültesi Dergisi 16 (2019), 75-121.

Çifçi, Mehmet Faruk. "Kemalpaşazâde'ye Göre Müşâkele Sanatı (Problemler ve Eleştiriler)”. Hitit Üniversitesi İlahiyat Fakültesi Dergisi 19/1 (2020), 119-150.

Eliaçık, Muhittin. “Şeyhülislam Kemalpaşazâde'nin Esrar ve Şarapla İlgili Tartışmalı, Latifeli Fetvâsı". International Journal of Language Academy 8/5 (2020), 20-27.

Eliaçık, Muhittin. "Şeyhülislam Kemalpaşazâde'nin Manzum Fetvaları”. Hikmet - Akademik Edebiyat Dergisi 13 (2020), 74-83.

İmamoğlu, Fatma. “Kemâl Paşazâde, Şemseddîn Sivâsî, Abdurrahîm Karahisârî, Esâsî ve Le'âlî’ye Ait Manzum Kaside-i Bürde Tercümelerinin Karşılaştırılarak İncelenmesi". International Journal of Filologia 4 (2020), 90-123.

İnanır, Ahmet. “Furûku'l-Usûl Adlı Risalenin Âidiyet Sorunu Üzerine Bir İnceleme Risale Şeyhülislam İbn Kemal'e mi Ait Yoksa Kazasker Manav İvaz Efendi'ye mi?". Usul İslam Araştırmaları 33/33 (2020), 1-27.

Orazov, Orazsahet. “Kemalpaşazâde'nin er-Risâle fî İstihsâni'l-İsti'câr alâ Ta'limi'l-Kur'ân Adlı Risalesi: Tahlil ve Çeviri". Kocaeli Üniversitesi İlahiyat Fakültesi Dergisi 4/1 (2020), 179-196.

Aktan, Muhammed Felat. "Kemalpaşazâde'nin İlk Mersiye Muhakemesi ve Tenkidi". Cihanşümul Akademi Sosyal Bilimler Dergisi 2/2 (2021), 19-27. 
Aydın, Mükerrem Bedizel - Yılmaz, Büşra Seda. "Şeyhülislam Kemalpaşazâde'ye Ait Bir Tip Risalesi: Fevâidü'l-Kemalpaşazâde". Amasya Üniversitesi Sosyal Bilimler Dergisi 9 (2021), 169-216.

Bakhtari, Muhammed Zakir - Kocaoğlu, Soner. "Kemalpaşazâde'nin Beyânu'lVücûd Risâlesinin Tahlil, Tahkik ve Tercümesi". Universal Journal of Theology 6/1 (2021), 247-289.

Demirkol, Murat. “Kemalpaşazâde'ye Göre Mahiyetin Mec'uliyeti”. Eskiyeni 43 (2021), 183-211.

Dinç, Ömer. “Osmanlı Tefsir Geleneği Çerçevesinde İbn Kemal Paşa'nın Gayb Ayetleri Hakkındaki Yorumları - Risâle fî Tahkîki'l-Gayb Özelinde Bir İnceleme -“. Tefsir Araştırmaları Dergisi 5/1 (2021), 426-461.

Ege, Ramazan. “İbn Kemal'in Tagyîru't-Telhis Adlı Risâlesi Edisyon - Kritik”. Bartın Üniversitesi İslami İlimler Fakültesi Dergisi 15 (2021), 6-22.

Eliaçık, Muhittin. “Şeyhülislam Kemalpaşazâde'nin Cinler Hakkında Manzum Fetvâsı ve Ahlât-1 Erbaa Açısından Tahlili". Erdem 80 (2021), 29-42.

Maden, Şükrü. “Tefsir Hâşiye Edebiyatının Karakteristik Bir Özelliği Olarak Eleştiri: Sa'dî Çelebi'nin İbn Kemâl Paşa'ya Yönelik Bazı Eleştirilerinin Tahlili”. Mutalaa 1/1 (2021), 36-55.

Tekin, Özkan. “İbn Kemal'in Bazı Metafizik Meseleler Konusunda Cürcânî’ye Yönelttiği Eleştiriler". Danişname Beşeri ve Sosyal Bilimler Dergisi 2 (2021), 191-210.

Tekin, Özkan. "Kemalpaşazâde'ye Göre Şerrin Allah'a Nispeti Problemi”. Journal of Analytic Divinity 5/2 (2021), 197-211.

Toksöz Hatice - Gün, Rabia. "Kemalpaşazâde'nin İsbât-1 Vâcib Yorumu ve Katkısı". Danişname Beşeri ve Sosyal Bilimler Dergisi 2 (2021), 19-40.

Ünverdi, Mustafa - İlbaylı, Şeyma. “Osmanlı Kelâm Geleneğinde İbn Kemâl ve Mehmed Birgivî”. Batman Akademi Dergisi 5/1 (2021), 43-72.

\subsection{Tebliğler}

Türker Küyel, Mübahat. "İbn-i Kemâl Paşa ve Tehâfüt Haşiyesi”. VIII. Türk Tarih Kongresi, Ankara: 11-15 Ekim 1976, Kongreye Sunulan Bildiriler. 2/993-994. Ankara: Türk Tarih Kurumu Yayınları, 1981.

Uğur, Ahmet. "Kemal Paşa-Zade'nin VIII. ve IX. Defterleri ve Bu Defterler Işığında Yazarın Tarihçiliği". VIII. Türk Tarih Kongresi, Ankara: 11-15 Ekim 1976, Kongreye Sunulan Bildiriler. 2/1007-1019. Ankara: Türk Tarih Kurumu Yayınları, 1981. 


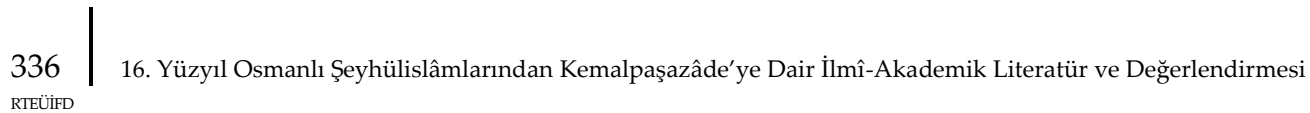

Fayda, Mustafa. "İbn Kemal'in Hayatı ve Eserleri". Şeyhülislâm İbn Kemâl Sempozyumu: Tebliğler ve Tartışmalar. ed. S. Hayri Bolay vd. 53-60. Ankara: Türkiye Diyanet Vakfı Yayınları, 1986.

Güzel, Abdurrahman. "Kemal Paşazâde'nin Eserlerinde Türk Halk Edebiyatı'na Ait Bazı Motifler". Şeyhülislâm İbn Kemâl Sempozyumu: Tebliğler ve Tartışmalar. ed. S. Hayri Bolay vd. 211-227. Ankara: Türkiye Diyanet Vakfı Yayınları, 1986.

Cumbur, Müjgan. “İbn Kemal'in Şiirleri ve Yavuz Selim Mersiyesi”. Türk Tarihinde ve Kültüründe Tokat Sempozyumu: 2-6 Temmuz 1986. haz. S. Hayri Bolay vd. 573-587. Ankara: Gelişim Matbaası, 1987.

Kavcar, Cahit. “İbn Kemal'in Şairliği ve Yusuf'u Züleyha'sı". Türk Tarihinde ve Kültüründe Tokat Sempozyumu: 2-6 Temmuz 1986. haz. S. Hayri Bolay vd. 587-595. Ankara: Gelişim Matbaası, 1987.

Kaya, Mahmut. “İbn Kemal'in Düşünce Tarihimizdeki Yeri ve Varlık Anlayışı”. Türk Tarihinde ve Kültüründe Tokat Sempozyumu: 2-6 Temmuz 1986. haz. S. Hayri Bolay vd. 595-603. Ankara: Gelişim Matbaası, 1987.

Öçal, Şamil. “Mevlânâ ve Kemalpaşazâde'de Varlık Kavramı ve Işık Sembolü”. Mevlânâ Araştırmaları 3. ed. Adnan Karaismailoğlu. 125-136. Ankara: Akçă̆ Yayınları, 2009.

Öçal, Şamil. "Kemalpaşazade: Bir Osmanlı Filozofu". Tokat'ın Yetiştirdiği İlim ve Fikir Önderleri. ed. Kadir Özköse. 64-85. Tokat: Gaziosmanpaşa Üniversitesi İlahiyat Fakültesi Yayınları, 2014.

Sarıkaya, Muammer. "İbn Kemal'in Arapça Vurgusu”. Tokat'ın Yetiştirdiği İlim ve Fikir Önderleri. ed. Kadir Özköse. 85-118. Tokat: Gaziosmanpaşa Üniversitesi İlahiyat Fakültesi Yayınları, 2014.

Alper, Ömer Mahir. “XVI. Yüzyılda Osmanlı Düşüncesi: Kemalpaşazâde Bağlamında Bazı Mülâhazalar". Sahn-ı Semân'dan Dârülfünûn'a Osmanlı'da İlim ve Fikir Dünyası, Âlimler, Müesseseler ve Fikrî Eserler XVI. Yüzyıl. ed. Ekrem Demirli vd. 15-20. İstanbul: Zeytinburnu Belediyesi Kültür Yayınları, 2017.

Apaydın, Yusuf. “Kemalpaşazâde'nin “Tabakâtu'l-Fukahâ"sı Neyi Anlatıyor?”. Sahn-ı Semân'dan Dârülfünûn'a Osmanlı'da İlim ve Fikir Dünyası, Âlimler, Müesseseler ve Fikrî Eserler XVI. Yüzyıl. ed. Ekrem Demirli vd. 99-104. İstanbul: Zeytinburnu Belediyesi Kültür Yayınları, 2017.

Demirli, Ekrem. “Osmanlı Düşüncesinin Ufku İmtizaç Devrinin Sorunlarıyla Malul Bir Düşünce Hayatı: Kemalpaşazâde' nin Mahiyetler Risalesi ve Öteki Risaleleri Üzerine Mülahazalar". Sahn-ı Semân'dan Dârülfünûn'a Osmanlı'da İlim ve Fikir Dünyası, 
Âlimler, Müesseseler ve Fikrî Eserler XVI. Yüzyıl. ed. Ekrem Demirli vd. 235-244. İstanbul: Zeytinburnu Belediyesi Kültür Yayınları, 2017.

Erkoçoğlu, Fatih. “Hüseyin Hüsameddin'in Kemalpaşazâde'nin Amasyalı Olduğu İddiasını İspat Çabasına Tarihçilik Açısından Bakış". Uluslararası Amasya Âlimleri Sempozyumu Bildiriler Kitabı - 2. ed. Şuayip Özdemir - Ayşegül Gün. 2/413423. Ankara: Kibatek, 2017.

Yığın, Adem. “F1kıh Usûlünü Eleştirmek: İbn Kemâl'in Kitâb’ın (Kur'ân) Mânâ İfade Etme Biçimleri Üzerinden Sadruşşerîa Eleştirisi”. Osmanlı'da İlm-i Fıkıh: Âlimler, Eserler, Meseleler. ed. Mürteza Bedir vd. 185-224. İstanbul: İSAR Yayınları, 2017.

Yıldırım, İlyas. "Kemâlpaşazâde'nin Tenkîh Eleştirisi”. Osmanlı'da İlm-i Fıkıh: Âlimler, Eserler, Meseleler. ed. Mürteza Bedir vd. 54-79. İstanbul: İSAR Yayınları, 2017.

Aydın, Mehmet. "Zihnî Varlığın Aslî Varlık Oluşu: İbn Kemal Paşa ve Taşköprülüzade Arasında Bir Tartışma”. Osmanlı Düşüncesi: Kaynakları ve Tartışma Konuları. ed. Fuat Aydın vd. 103-115. İstanbul: Mahya Yayınları, 2018.

Ceyhan, Semih. “Osmanlı Şeyhülislâmlarının Tasavvuf Literatürüne Katkısı: Kemalpaşazâde'nin Risâle fî 'ulûmi'l-hakâyık'1". Osmanlı'da İlm-i Tasavvuf. ed. Ercan Alkan - Osman Sacid Arı. 659-685. İstanbul: İSAR Yayınları, 2018.

Üstün, İsmail Safa. "XVI. Yüzyıl Osmanlıların Meşruiyeti Meselesi ve Kemalpaşazâde'nin “Zendeka" Risalesi”. Osmanlı'da İlm-i Tasavvuf. ed. Ercan Alkan Osman Sacid Arı. 633-658. İstanbul: İSAR Yayınları, 2018.

Bahçeci, Rabia Hacer. "İbn Kemal Tefsirinde Lugavî ve Örfî Hakikat". Osmanlı'da İlm-i Tefsir. ed. M. Taha Boyalık - Harun Abac1. 457-478. İstanbul: İSAR Yayınları, 2019.

Söylev, Ömer Faruk. “Şeyhülislam İbn Kemal'e Göre Ruhun Mahiyeti ve Beden ile İlişkisi". 4th International Social Research and Behavioral Sciences Symposium. ed. Kiyal Kamchybekova Abdiraim. 532-537. b.y.: y.y., 2019.

Öçal, Şamil - Koçak, Mustafa. “Kemalpaşazâde'nin Varlık Görüşü: Kaynakları ve Kelâmî, Felsefî, Tasavvufî Boyutları". Uluslararası 14. ve 15. Yüzyıl İslam Düşüncesinde Felsefe, Kelam ve Tasavvuf Sempozyumu Bildirileri. ed. Murat Demirkol vd. 1/149-162. Ankara: Ankara Yıldırım Beyazıt Üniversitesi Yayınları, 2020.

\subsection{Neşir ve Tahkikler}

Kemalpaşazâde, İbn Kemal Ahmed Şemseddin. Risâle fì beyân-ı evșâf-ı Ümmi'lKitâb ve levh-i mahfuz ve leḥv-i manevî. İstanbul: Darü't-Tıbaati'1-Âmire, 1264. 


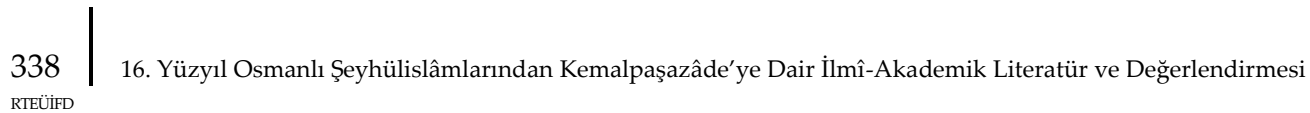

Kemalpaşazâde, İbn Kemal Ahmed Şemseddin. Mohacnâme-i Kemalpaşazâde. Paris: Matbaa-i Sultaniye, 1859.

Kemalpaşazâde, İbn Kemal Ahmed Şemseddin. el-Felâh şerḥu'l-Meraḥ. İstanbul: Matbaa-i Âmire, 1872.

Kemalpaşazâde, İbn Kemal Ahmed Şemseddin. Terceme-i risâle-i ta'rîbât. İstanbul: el-Cevaib Matbaası, 1290.

Kemalpaşazâde, İbn Kemal Ahmed Şemseddin. "et-Tenbîh 'alâ galați'l-câhil ve'nnebîh”. Țurafun 'Arabiyye. nşr. Ömer es-Süveydî. 2-24. Leiden: Matbaatü Beril, 1303.

Kemalpaşazâde, İbn Kemal Ahmed Şemseddin. el-Felâh şerḥu'l-Merâh. İstanbul: Karabet ve Kasbar Matbaası, 1304.

Kemalpaşazâde, İbn Kemal Ahmed Şemseddin. "Risâletü'l-ihtiliâf beyne'lEşâ'ira ve'l-Mâturîdiyye fî išnetey 'aşrate mes'eleten”. Hams Risâle. nşr. Mustafa Lutfi Efendi. 57-59. İstanbul: Cemal Efendi Matbaası, 1304.

Kemalpaşazâde, İbn Kemal Ahmed Şemseddin. Risâletü'l-münîre. İstanbul: Cemal Efendi Matbaası, 1308/1890.

Kemalpaşazâde, İbn Kemal Ahmed Şemseddin. Tag்yîrü't-tenkîhh fi'l-ușûl. İstanbul: Cemal Efendi Matbaası, 1308/1890.

Kemalpaşazâde, İbn Kemal Ahmed Şemseddin. Kemâl Paşazâde Dîvânı. İstanbul: İkdam Matbaası, 1313/1895.

Kemalpaşazâde, İbn Kemal Ahmed Şemseddin. Resâil-i İbn Kemâl. nşr. Ahmed Cevdet. İstanbul: İkdam Matbaası, 1315/1898.

Kemalpaşazâde, İbn Kemal Ahmed Şemseddin. Hadîș-i Erba'în Tercemesi. çev. Âşık Nitâî. İstanbul: Cemal Efendi Matbaası, 1316.

Kemalpaşazâde, İbn Kemal Ahmed Şemseddin. Şerḥ-i hadîș-i erba'în. İstanbul: Cemal Efendi Matbaası, 1316.

Kemalpaşazâde, İbn Kemal Ahmed Şemseddin. Leâli-i me'ânî. İstanbul: Artin Asaduryan Matbaası, 1328/1910.

Kemalpaşazâde, İbn Kemal Ahmed Şemseddin. fi't-Ta'rîb. çev. Ahmed Hattâb el-Ömer. Musul: Câmi'atü'1-Musul, 1403/1983.

Kemalpaşazâde, İbn Kemal Ahmed Şemseddin. Dirâsât fî̀ te'șîli'l-mu'arrabât ve'lmuṣtalah. nşr. Hâmid Sâdık Kuneybî. Beyrut: Dârü'l-Cil, 1991. 
Kemalpaşazâde, İbn Kemal Ahmed Şemseddin. "Risâle fî taḥ̣̂̂ḳi't-tağlîb". Risâletân fì luggati'l-Kur'ân. nşr. Sâhib Ebû Cenâh. 89-131. Ammân: Dâru'1-Fikr, $1419 / 1999$.

İbn Kemal (Kemalpaşazâde). Tevârih-i Âl-i Osman IV. Defter. haz. Koji Imazawa. Ankara: Türk Tarih Kurumu, 2000.

Kemalpaşazâde, İbn Kemal Ahmed Şemseddin. er-Resâilü'l-akdiyye. thk. Cum’a Mustafa el-Feyuri. Beyrut: Dârü'l-Medâri'l-İslâmi, 2002.

Kemalpaşazâde, İbn Kemal Ahmed Şemseddin. Yûsuf u Zelîhâ. nşr. Şinasi Tekin - Gönül Alpay Tekin. Cambridge: Harvard University, 2004.

Kemalpaşazâde, İbn Kemal Ahmed Şemseddin. et-Tenbîh 'alâ ġalațill-câhil ve'nnebîh. thk. Abdülkadir el-Magribi. Beyrut: Darü'l-Muktebes, 1435/2014.

Kemalpaşazâde, İbn Kemal Ahmed Şemseddin. Şerḥu Riyâżi'ṣ-șâlihîñ el-Fevâidü' mütra'atü'l-hiyấz fî şerḥ-i Kitâbi'r-riyâż. thk. Nureddin Talib vd. 7 Cilt. Beyrut: Darü'nNevâdir; Dımaşk: Vizaretü'l-Evkaf ve'ş-Şuuni'1-İslâmiyye, 1435/2014.

Kemalpaşazâde, İbn Kemal Ahmed Şemseddin. Tefsîru İbn Kemâlpaşâzâde min evveli sûreti'l-Fâtiḥa ilâ ahiri sûreti'n-Nisâ. thk. İzzeddin Cüleyd. 3 Cilt. Rabat: Menşuratu Vizâretü'1-Evkâf ve'ş-Şuuni'l-İslâmiyye, 1435/2014.

Kemalpaşazâde, İbn Kemal Ahmed Şemseddin. Tefsîru İbn Kemâl Bâşâ. thk. Mahir Edib Habbuş. 9 Cilt. İstanbul: Mektebetü'1-İrşad, 1439/2018.

Kemalpaşazâde, İbn Kemal Ahmed Şemseddin. Mühimmâtü'l-müftî fi fürû'i'lHanefiyye. thk. Abdülaziz b. Abdullah b. Abdülaziz el-Ammar. 2 Cilt. Riyad: Mektebetü'n-Neşir, 1440/2019.

\subsection{Ansiklopedi Maddeleri}

Ménage, V. L. "Kemāl Pasha-Zāde". Encyclopaedia of Islam (Second Edition). ed. P. Bearman vd. Erişim 16 Ağustos 2021. http://dx.doi.org/10.1163/15733912_islam_com_0480.

"İbni Kemal, Şemseddin Ahmed". Cumhuriyet Ansiklopedisi. 6/1729. İstanbul: Arkın Kitabevi, 1972.

Karahan, Abdulkadir. "Kemâl Paşazâde". Meydan Larousse Büyük Lügat ve Ansiklopedi. ed. Safa Kılıçoğlu vd. 7/159-160. İstanbul: Meydan Yayınevi, 1971.

"Kemalpaşaoğlu, Şemseddin Ahmed". Türk Ansiklopedisi. 21/478-481. Ankara: Millet Eğitim Basımevi, 1974. 


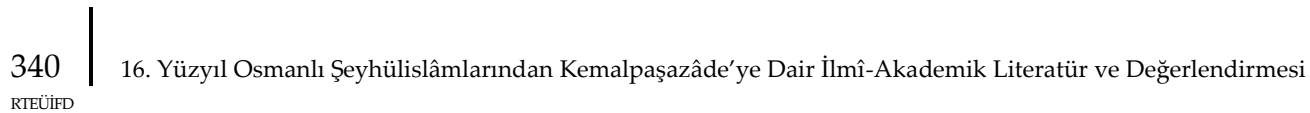

Özkırımlı, Atilla. "Kemal Paşazâde". Türk Edebiyatı Ansiklopedisi. 3/741-742. İzmir: Cem Yayınevi, 1982.

"Kemâlpaşa-zâde Ahmed Şemseddin Efendi". Yeni Türk Ansiklopedisi. 5/1787. İstanbul: Ötüken Neşriyat, 1985.

"Kemâl Paşazâde". Başlangıcından Günümüze Kadar Büyük Türk Klasikleri. 3/264271. İstanbul: Ötüken Neşriyat, 1986.

“Kemalpaşazade”. AnaBritannica. 13/165-166. İstanbul: Ana Yayıncılık, 1989.

"Kemalpaşazade". Büyük Larousse Sözlük ve Ansiklopedisi. 13/6608. İstanbul: Milliyet Yayınları, 1992.

"İbn-i Kemâl Paşa". Yeni Rehber Ansiklopedisi. 9/282-284. İstanbul: Türkiye Gazetesi, 1993.

“İbni Kemal”. Büyük Ansiklopedi. 6/2340. İstanbul: Milliyet Yayınları, 1990.

Pala, İskender. "Kemalpaşazâde". Osmanlı Ansiklopedisi. 2/158-163. İstanbul: İz Yayıncilık, 1996.

Uluçam, Müjdat. “İbni Kemal”. Yaşamları ve Yapıtlarıla Osmanlılar Ansiklopedisi. 1/606-609. İstanbul: Yapı Kredi Yayınları, 2. Basım, 2008.

"Kemâlpaşazâde, Ahmed Şemseddin Efendi". Türk Dili ve Edebiyatı Ansiklopedisi. 5/275. İstanbul: Dergâh Yayınları, 1982.

Kalın, İbrahim. "Ibn Kemal". The Biographical Encyclopaedia of Islamic Philosophy. ed. Oliver Leaman. London: Thoemmes Continuum, 2006.

Saraç, Yekta. "Ibn Kamāl". The Oxford Encyclopedia of Philosophy, Science and Technology in Islam. Oxford: Oxford University Press, 2014.

Tiryaki, Mehmet Zahit. "Kemalpaşazâde". İstam Düşünce Atlası. ed. İbrahim Halil Üçer. 2/579-581. İstanbul: Konya Büyükşehir Belediyesi Kültür Yayınları, 2017.

Turan, Şerafettin vd. “İbn Kemal”. Temel İslam Ansiklopedisi. ed. Tuncay Başoğlu. 4/150-152. Ankara: Türkiye Diyanet Vakfı Yayınları, 2019.

\section{Arapça Çalışmalar}

Arapça çalışmaların transkripsiyonunda İSNAD'ın belirttiği kılavuz esas alınmıştır.

\subsection{Doktora Tezleri}

Berrî, Cebr İbrahim Muhammed. Tag்yîru'l-miftâh li İbn Kemâl Bâşâ 940 h.: dirâse ve tahkîk. Amman: el-Câmi'atü'l-Ürdüniyye, Doktora Tezi, 2010. 
el-'Âyidî, Muhammed Subhi Hasan. Kitabu "Taġyîru't-tenkîh ve şerḥhû": dirâseten ve tahkîkan: te'lîf el-imâm Şemseddin Ahmed b. Süleyman b. Kemâl Bâşâ elmüteveffâ sene 940 h.: el-cüz'ü'l-evvel: min evveli'l-kitâb ilâ bidâyeti rukni's-sünne. Amman: Câmi'atü'1-'Ulûmi'l-İslâmiyyeti'1-'Âlemiyye, Doktora Tezi, 2010.

Mesâd, Abdullah Hasan Yusuf. Şerḥu tag்yîru't-tenkîhh li'l-imâm şeyhu'l-İslâm Ahmed b. Süleyman b. Kemâl Bâş̧â (873-940 h.) min evoli'r-rukni'-sââ̂ fi's-sünneti ilâ evveli bâbi'l-mu'âraża ve't-tercîh: tahkîk ve dirâse. Amman: Câmi'atü'l-'Ulûmi'l-İslâmiyyeti'l'Âlemiyye, Doktora Tezi, 2010.

el-Maḥrûk, 'Amr Halîfe. Şerḥu ferâiżi'l-imâm es-Secâvendî (600 h) li'l-imâm Şemseddin Ahmed b. Süleyman Kemâl Bâş̧â eş-şehîr bi İbn Kemâl Bâşâ (940 h) min bidâyeti (fașlün fî ma'rifeti't-temâsül ve't-tedâhül ve't-tevâfuk ve't-tebâyün) ilâ (âhiri faṣl fi'l-garkâa): dirâse ve tahkîk k. Omdurman: Omdurman: Câmi'atü Ümm-ü Dermân el-İslâmiyye, Doktora Tezi, 2015.

Nezdef, Muhammed Sultan Ali. Şerḥu ferâizi's-sirâciyye li İbn Kemâl Bâş̧â min bidâyeti'l-kitâb ilâ âhiri babi'l-'avl: dirâse ve tahkîk. Omdurman: Câmi'atü Ümm-ü Dermân el-İslâmiyye, Doktora Tezi, 2015.

\subsection{Yüksek Lisans Tezleri}

Ḳımâş, Garîb Mahmut. İbn Kemâl Bâşâ ve ârâuhû'l-kelâmiyye ve'l-felsefiyye me'a tahkîkịi ba'żı resâilihi'l-kelâmiyye ve'l-felsefiyye. Kahire: Kahire Üniversitesi, Yüksek Lisans Tezi, 1991.

Arpa, Enver. Tefsîru İbn Kemâl Bâşâa: dirâse ve tahkîk min hilâli süveri Hûd ve Yûsuf $v e^{\prime} r$-Ra'd. Amman: el-Câmi'atü'l-Ürdüniyye, Yüksek Lisans Tezi, 1994.

eş-Şimrânî, Abdullah Muhammed. et-Tefkîru'n-naḩồ 'inde İbn Kemâl Bâşâ fî kitâbihî Esrâri'n-Nâhv. el-Kerak: el-Câmi'atü’l-Mu'te, Yüksek Lisans Tezi, 2011.

es-Sinânî, Bühayt b. Hammûd b. Cezâ'. Şerḥu Tağyîri'l-miftâh li İbn Kemâl Bâşâ elmüteveffâ sene 940 h.: dirâse ve tahkînk. Medine: el-Câmi'atü'l-İslâmiyye bi'l-medîneti'lmünevvera, Yüksek Lisans Tezi, 2011.

Ahmed, Tahsin Ahmed Muhammed. Cuhûdu İbn Kemâl Bâşâ fi't-tefsîr. Sudan: International University of Africa, Yüksek Lisans Tezi, 2011.

Yıldırım, Menduh. Tefsîru İbn Kemâl Bâşâ li's-sûreti'l-En'âm: dirâse ve taḥkiḳ. Amman: el-Câmi'atü'l-Ürdüniyye, Yüksek Lisans Tezi, 2011.

Temel, Nihat. Tabakâtü'l-fukahâ bi'tibâri merâtibihimi'l-'ilmiyye fi'l-mezâhibi'l-erba'a. Yalova: Yalova Üniversitesi, Sosyal Bilimler Enstitüsü, Yüksek Lisans Tezi, 2019. 
\begin{tabular}{l|l}
342 & 16. Yüzyıl Osmanlı Şeyhülislâmlarından Kemalpaşazâde'ye Dair İlmî-Akademik Literatür ve Değerlendirmesi \\
RTEÜFD &
\end{tabular}

\subsection{Makaleler}

el-Maġribî, Abdülkadir. "el-Lügatü'1-'arabiyye fî devleti't-Türki'1-'Oșmâniyyîn: ta'lị̂ 'alâ risâleti't-Tenbîh". Mecelletü'l-Mecma'i'l-'Ilmî el-'Arabî 6-5-6 (1926), 217-223.

el-Maġribî, Abdülkadir. "et-Tenbîh ‘alâ galați'l-câhil ve'n-nebîh -2-“. Mecelletü'lMecma'i'l-'ilmî el-'Arabî 6/1-2 (1926), 90-96.

el-Maġribî, Abdülkadir. “et-Tenbîh ‘alâ galați'l-câhil ve'n-nebîh -3-“. Mecelletü'lMecma'i'l-'̇lmî el-'Arabî 6/3-4 (1926), 134-141.

el-Magribî, Abdülkadir. “et-Tenbîh ‘alâ galați'l-câhil ve'n-nebîh -4-“. Mecelletü'lMecma'i'l-'́lmî el-'Arabî 6/3-4 (1926), 174-180.

el-Maġribî, Abdülkadir. "Neşru risâletin mahțûṭâtin fî ıṣlâḥi ag̉lâț kelâmi'nnâs". Mecelletü'l-Mecma'i'l-'Ilmî el-'Arabî 6/1-2 (1926), 43-48.

Maḥfûz, Hüseyin Ali. "Risâle fî taḥkị̂ḳi lafẓı'z-zındîḳ ve tavżîhi ma'nâhü lügaten ve şer'an ve beyâni ḥukmihî li İbn Kemâl Bâşâ el-müteveffâ sene 940 h.". Mecelletü'lÂdâb 5 (1962), 45-46.

el-'Abîdî, Reşit Abdurrahman. "Taḥkîḳu ma'nâ (kâde) li İbn Kemâl Bâşâ". Mecelletü Külliyeti'd-Dirâsâti'l-İslâmiyye 5 (1973), 311-344.

'Itr, Hasan Ziyaeddin Muhammed. “Tefsîru sûreti'l-Mülk li Şemdeddin b.

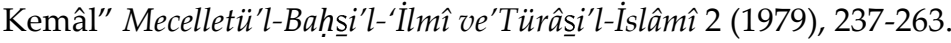

el-'Abîdî, Reşit Abdurrahman. "Kitâbü't-tenbîh 'alâ galați'l-câhil ve'n-nebîh li İbn Kemâl Bâşâ 940 h.”. el-Mevrid 9/4 (1980), 551-598.

Cevherci, Muhammed Adnan. “Risâletü't-tenbîh 'alâ galațı'l-câhil ve'n-nebîh ve nisbetühâ li İbn Kemâl Bâşâ". Mecelletü Mecma'i'l-Lüğati'l-'Arabiyye bi Dimaşk 61/4 (1986), 830-837.

Hasan, Cafer Hâdî. “Ṭarîkatü târîhi İbn Kemâl Bâşâ fî'l-mahțûții'l-İslâmî”. 'Alemü'l-Kütüb 7/2 (1986), 164-170.

Kuneybî, Hâmid Sadık. "Risâle fî medâri't-tecevvüz fi'l-lafẓ". Mecelletü'lMu'cemiyye 4 (1987), 123-150.

Ebu'l-Futûh, Muhammed Hüseyin. "el-Farḳ beyne min et-teb'îżiyye ve min ettenbîhiyye". ed-Dâra 14/2 (1988), 121-141.

Kuneybî, Hâamid Șâdıḳ. "Dirâsât fî te'ṣîli'l-mu'arrabât ve'l-mușțalah min hiilâli dirâse 'Taḥkîkụu ta'rîbi'l-kelimeti'l-a'cemiyye' li İbn Kemâl Bâşâ müteveffâ 940 h.”. elLisânü'l-'Arabî 30 (1988), 161-200. 
Kuneybî, Hâmid Ṣâdıḳ. "Dirâsât fî te'ṣ̂ili'l-mu'arrabât ve'l-mușțalah min hilâli dirâse 'Tahḳîku ta'rîbi'l-kelimeti'l-a'cemiyye' li İbn Kemâl Bâşâ müteveffâ 940 h., elḳısmü's s-sânî”. el-Lisânü'l-'Arabî 31 (1988), 97-156.

Kuneybî, Hâmid Sadık. “el-Hुavâș ve'l-mezâyâ fi'l-uslûbi'l-belâgî: ḳırâa' ve taḳvimiyye ve taḥ̣̂̂ḳ" Buḥ̣̂ ve Dirâsât fi'l-Lugiati'l-'Arabiyyeti ve Âdâbihâ 2 (1988), 511-552.

Feccâl, Mahmut b. Yûsuf. “İbn Kemâl Bâşâ, hayatühû ve müellefâtihî”. 'Âlemü'lkütüb 10/3 (1989), 340-352.

Kuneybî, Hâmid Sadık. "Risâle fî medâri't-tecevvüz fi'l-lafẓ”. Mecelletü Mecma'i'l-Lügati'l-'Arabiyye el-Ürdüniyye 13/36 (1989), 279-297.

Ebü'l-Futûh, Muhammed Hüseyin. "Risâle fî beyâni mâ izâa kâne șâhibu 'ilmi'lme’ânî yüşâriku'l-lügavî fî́l-baḥsi ‘an müfredâti'l-elfâzịi li İbn Kemâl Bâşâ (940 h.)”. ed-Dâra 15/3 (1990), 186-212.

Feccâl, Mahmut b. Yûsuf. "Nuṣûșun türâsiyyetün muhạḳạakatün: risâle fî nisbeti'l-cem' li İbn Kemâl Bâşâ". 'Âlemü'l-Kütüb 13/6 (1992), 616-624.

Ebû Cenâh, Sâhịib. “Taḥḳ̂ḳu't-taglîb”. el-Mevrid 21/1 (1993), 98-109.

Ebu'l-Futûh, Muhammed Hüseyin. “Risâle fîmâ yüfîdü vâvü'l-aṭıf: li İbn Kemâl Bâşâ 940 h.: dirâse ve taḥkị̂". Mecelletü Câmi'ati'l-Meliki Su'ûd-el-Âdâb 10/1 (1998), 35-51.

Miftâh, Rabâh el-Yemenî. “Taḥḳ̣̣̂̂u vaż'i kâde ve tavżịḥ țarîḳi isti’mâlihî”. Mecelletü Külliyeti Dâri'l-'Ulûm 27 (1999), 127-188.

Nasr, Cemal Muhammed Muhammed. "Risâle fî taḥkîḳi vażı (kâde) li İbn Kemâl Bâşâ dirâse ve taḥ̣̣̂̂" . eś-șekâfe ve't-Tenmiye 2 (2001), 169-223.

İbrahim, Muhammed b. Ali. “Taḥḳ̂̂ku'l-münâsebe ve'l-mülâeme ve't-te'ŝ̂r te'lîfü'l-'allâme Ahmed b. Süleyman eş-şehîr bi İbn Kemâl Bâşâ el-müteveffâ 940 h." Mecelletü Câmi'ati Ümmi'l-Kurâ li 'Ulûmi'ş-Şerî'a ve'l-Lüğati'l-'Arabiyye ve Âdâbihâ 15/27 (2003), 327-359.

'Ațavî, Muhammed Abdülfettah. "et-Tenbîh 'alâ galați'l-câhil ve'n-nebîh li Ahmed b. Süleyman el-ma' rûf bi İbn Kemâl Bâşâ 940h.". Mecelletü'l-Buhûs ve'd-Dirâsât fìl-ÂAâb ve'l-'Ulûm ve't-Terbiye 2 (2004), 132-140.

ed-Derâvîş, Hüseyin Ahmet Ali. "Risâle fî hurûfi'l-Ḳur'ân li İbn Kemâl Bâşâ elmüteveffâ sene 940 h/1534 m”. Mecelletü Câmi'ati'l-Kudüsi'l-Meftûha li'l-Buhûsisi'lİnsâniyye ve'l-İctimâ'iyye 5 (2005), 224-256.

eț-Ṭavâlibe, Muhammed Abdurrahman. "Risâle fî taḥkîḳi'l-ḳavli bi enne'şşühedâ' ehyaün fi'd-dünyâ li İbn Kemâl Bâşâ: 940 h. rahiimehullah". Mecelletü'l-Menâra li'l-Buḥ̂̂s ve'd-Dirâsât 11/3 (2005), 155-188. 


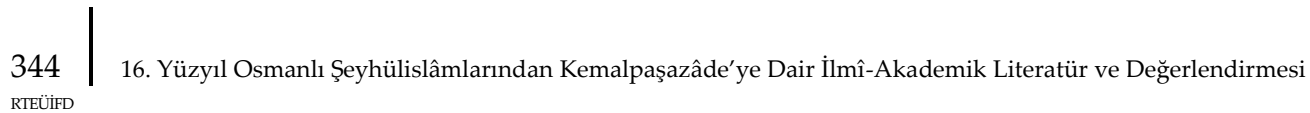

et-Türkî, İbrahim b. Mansur. "Risâletü't-tevessü'ât: dirâse ve tahḳ̂ị”. 'Âlemü'lMahțûtâti ve'n-Nevâdir 11/1 (2006), 4-27.

Kuneybî, Ḥâmid Ṣ̂âlı̣. “Müşâreketü șâhibi'l-me'ânî'l-lügavî fî̀l-baḥsi 'an müfredâti'l-elfâz ev (müfredâti'l-elfâz beyne 'ilmi'l-me'ânî ve 'ulûmi'l-lugia) li İbn Kemâl Bâşâ el-müteveffâ 940 h.: ḳırâe’ taḳvîmiyye ve tahḳîḳ”. el-Mevrid 35/3 (2008), 79-97.

el-Ḥâc Abdülemir, Mahmud Şemseddin. "Kitâbu Șafveti'l-menḳûlât fî şerḥi şurûți'ṣ-șalât". Mecelletü Külliyeti't-Terbiye 2 (2010), 49-155.

'Ammâd, Hamid Ahmed el-Ḥazrecî. “ed-Dersu'ș-ṣavtî 'inde İbn Kemâl Bâşâ (940 h.) fî kitâbihî (el-Felâh fî şerhi'l-Merâh)”. Mecelletü Surra men Ra'â 7/24 (2011), 129-150.

Berrî, Cebr İbrahim. “Risâle fî taḳsîmi'l-mecâz li İbn Kemâl Bâşâ (940 h.): dirâse ve tahkị̣̂̂". Dirâsât - el-'Ulûmu'l-İnsâniyye ve'l-İctimâ'iyye 38/2 (2011), 491-505.

el-Hुazracî, Safâ Cafer 'Ulvân. "Risâle fî̀ mușțalahâati'l-muhaddisîn: li İbn Kemâl Bâşâ - rahimehullahi te’âlâ -“. Mecelletü'l-Üstâz li'l-'Ulûmi'l-İnsâniyye ve'l-İctimâ'iyye 145 (2011), 238-289.

Bû‘alî, Muhammed Emin. "Risâle İbn Kemâl Bâşâ fî beyâni enne sâhibe 'ilmi'lme’ânî yüşârikü'l-lügavî fi'l-baḥsi 'an müfredâti'l-elfâz 'arż ve taḥ̣̂̂ḳ”. Mecelletü Mecma'i'l-Lügati'l-'Arabiyye bi Dimaşk 87/4 (2012), 1025-1042.

es-Serâkı̣bî, Velîd b. Muhammed. "Risâletân nâdiratân li İbn Kemâl Bâşâ: risâle fî enne esmâ Allahi tevḳ̂fiyye ve risâle ilâ nisbeti'l-cem'". Mecelletü Mecma'i'l-Lüğati'l'Arabiyye bi Dimaşk 87/1 (2012), 129-150.

el-Harbî, Abdülvahid b. Muhammed b. 'Îd. "Hुıțâbü'l-vâhid hıtṭâbü'l-isnneyn: “li İbn Kemâl Bâşâ". Mecelletü Külliyeti Dari'l-'Ulûm 68 (2013), 451-503.

eș-Ṣagînr, Mîlûd Mîlâd. "Risâle fî nisbeti'l-cem' li İbn Kemâl Bâşâ 940 h.". Mecelletü'l-lisâni'l-mübîn 8 (2013), 265-283.

Mecid, Vahîide Abdülhâhlı̣. “er-Risâletü'l-ḩiżabiyye: li'l-imâmi'l-'âlem Şemseddin Ahmed b. Süleyman b. Kemâl Bâşâ el-ma'rûf bi İbn Kemâl Bâşâ er-rûmî 940 h.". Mecelletü'l-Buhûs ve'd-Dirâsâti'l-İslâmiyye 33 (2013), 460-494.

Salâh, Muhammed Sâlim Ebü'l-Ḥac. "el-İntikââât 'alâ țabaḳâti İbn Kemâl Bâşâ". Usûl: İslam Araştırmaları 24 (2015), 105-130.

Zîbâî, Münir. "Risâle fî mușțalahâti'l-muhaddisîn, te'lîf Ahmed b. Süleyman b. Kemâl Bâşâ (940 h.)”. Mecelletü'l-Buḥ̂usisi'l-'ilmiyye ve'd-Dirâsâti'l-İslâmiyye 10 (2015), 378-406.

Ebu'l-Hâc, Sâlih Muhammed Salim. “'Medḥu's-Sa'y ve zemmü'l-bațâle' li İbn Kemâl Bâşâ 940 h.: dirâse ve taḥ̣̣̂̂"̣". Mecelletü'l-Müdevvene 2/7 (2016), 236-261. 
Ebu'l-Haccâc, Salâh Muhammed Salim. “Ṭabaḳâtü'l-fukahahâ li İbn Kemâl Bâşâ, 940 h.". Mecelletü'ş-Şerî'a ve'd-Dirâsâti'l-İslâmiyye 31/106 (2016), 437-488.

İslim, ibni'-Sebtî. "Mahțûtâti resâili İbn Kemâl Bâşâ fî mektebeti Âli Habot”. el'Arab 51/9 (2016), 626-637.

el-'Abîdî, Ziyâd Reşit. “Risâle fî mes'eleti'l-cebr ve'l-ḳader li İbn Kemâl Bâşâ (940 h.): dirâse ve taḥḳ̂k" . Havliyyetü Külliyeti'd-Dirâsâti'l-İslâmiyyeti ve 'Arabiyyeti li'l-benât bi'l-İskenderiyye 33/3 (2017), 468-538.

El-Hुużayriyyü, Yâsir b. İbrahim b. Muhammed. "Beyânu miḳdari mefrûżi'lmesh mine'r-ra's li İbn Kemâl Bâşâ el-hanefî”. Mecelletü'l-'Ulûmi'ş-Şer'iyye 47 (2017), 105-159.

el-Veşmî, Abdullah b. Sâlih b. Süleyman. “I'câzü'l-Kur'ân bi belâgatihi li İbn Kemâl Bâşâ 940 h.". Cüzûr 48 (2017), 13-84.

Menaf, Mehdi Muhammed el-Musevî. “Tahḳ̣̂ḳu kitâbi İbn Kemâl Bâşâ el-vezîr (940 h.) (risâle fî taḥkîḳi ta'rîbi'l-kelimeti'l-a'cemiyye) dirâse naḳdiyye". Mecelletü Külliyeti't-Terbiyeti'l-Esâsiyye li'l-'Ulûmi't-Terbeviyye ve'l-İnsâniyye 34 (2017), 500-508.

Şimrânî, Abdullah Muhammed. “Meẓâhiru's-semâ' 'inde nuhati'l-ḳarni'l'âşiri'l-hicrî: İbn Kemâl Bâşâ nemûzecen”. Mecelletü Câmi'atü'l-Bahs li'l-'ulûmi'lInsâniyye 39/7 (2017), 11-62.

Berrî, Cebr İbrahim. “Risâle fî beyâni'l-ḥaḳîkâ ve'l-mecâz li İbn Kemâl Bâşâ 940 h.: dirâse ve tahḳ̣̂̂". Mecelletü Câmi'ati'l-Hüseyin b. Talâl li'l-Buhụ̂ s/2 (2018), 303-331.

Büşrâ, Ahmed Muhammed Emin - Câsim, el-Hâc Câsim. "Risâletân fî'l-lüga li İbn Kemâl Bâşâ (940 h.) dirâse ve tahkị̂ḳ". Mecelletü'l-Câmi'ati'l-'Irakiyye 40/3 (2018), 207-254.

Kanû, Ali Abdul. "Risâle fî taḥ̣̂̂ḳi enne'l-Kur'ân mu'ciz Şemseddin Ahmed b. Süleyman b. Kemâl Bâşâ, eş-şehîr bi İbn Kemâl Bâşâ (940 h.)". Mecelletü'l-'Ulûmi'lİslâmiyye 2/17 (2018), 980-1009.

Șûfiyye, Fażîle Muhammed. "İşârâtün te'vîliyye li âyi'ṣ-šakli'l-ekberi sürati Tebâreke: el-Âyât min (12-18) li İbn Kemâl Bâşâ (enmûzecen)". Temel İslâm Bilimleri Araştırmaları. ed. Hidayet Aydar vd. 127-156. İstanbul: Ensar Neşriyat, 2018.

Şimrânî, Abdullah Muhammed. “Mezâhiru's-semâ' 'inde nuhati'l-ḳarni'l'âşiri'l-hicrî: İbn Kemâl Bâşâ nemûzecen”. Mecelletü'l-Bahsis'l-'ilmî fi'l-Âdâb 10/19 (2018), 123-158. 
\begin{tabular}{l|l}
346 & 16. Yüzyıl Osmanlı Şeyhülislâmlarından Kemalpaşazâde' ye Dair İlmî-Akademik Literatür ve Değerlendirmesi \\
RTEÜirF &
\end{tabular}

el-'Azzâvî, Ömer Kạț̣̂n Abdüllatif. "Risâle fî taḥkị̂ịi efżaliyyeti Muhammed (a.s) li İbn Kemâl Bâşâ (rahịmehullah) - 940 h.". Mecelletü Câmi'ati Tikrît li'l-'Ulûmi'lİnsâniyye 26/9 (2019), 306-336.

Muhammed, Muhammed İbrahim Abdülhalim. "İbn Kemâl Bâşâ ve menhecühû fi't-tefsîr". Havliyyetü Külliyeti'd-Dirâsâti'l-İslâmiyyeti ve 'Arabiyyeti li'l-benât bi'lIskenderiyye 35/6 (2019), 116-157.

Zeybânî, Münir b. Abdülkerim. “ed-Dersü'l-'aḳâidî fî vücûbi's-sa'yi lițalebi'rruzk ve'n-nehyi 'ani't-tebațțuli min hilâli taḥḳ̂ḳi risâle medḥu's-sa'yi ve zemmu'lbațâleti li İbn Kemâl Bâşâ, 940 h.”. el-Mecelletü'l-Cezâiriyye li'l-Mahț̂utât 14/2 (2019), 149-172.

Arpa, Enver. "İbn Kemâl Bâşâ ve menhecuhû fi't-tefsîr". el-Mecelletü'l'İlmiyyetü'l-Muhakkemetü li Riaseti'ş-Şu'ûni'd-Dîniyyeti't-Türkiyye 2/1 (2020), 14-45.

Firâs, Fâżıl Ferhân el-Muhammedi - Furat, Semîr Ferec ed-Dûserî. “Risâle li'lmevlâ İbn Kemâl Bâşâ fî beyâni ('ademü nisbeti'ş-şer ilâ Allah Te'âlâ) li Ahmed b. Süleyman b. Kemal Bâşâ (940 h.) -dirâse ve taḥkîḳ-“. Mecelletü Surra men Ra'â 16/65 (2020), 803-836.

\subsection{Tebliğler}

Canpolat, Erhan Sadık. "Şeyhul'-İslâm İbn Kemâl Bâşâ 873-940 h., 1469-1534 m.". Tehavvülati'l-fikriyye fî'l-'âlemi'l-İslâmî: A'lâm ve kütüb ve harekât ve efkâr mine'l-karni'l'âşiri'l-hicrî ile'l-karni'ș-ŝân 'aşer el-hicrî. ed. 'Alyân el-Câlûdî. 97-104. Herndon: elMa'hedü'l-'Âlemî li'1-Fikri'l-İslâmî, 2014.

Sermînî, Muhammed Enes. “el-'Alâḳatü'l-mütebâdele beyne fuḳahâi'ş-Şâm ve beyne's-sulța ve'l-fuḳahâ fi'l-Anadol fi'l-ḳarni'ṣ-sâlis 'aşer el-hicrî: İbn 'Âbidîn - İbn Kemâl Bâşâ enmûzecen". Osmanlı'da İlm-i Fıkıh: Âlimler, Eserler, Meseleler. ed. Mürteza Bedir vd. 387-430. İstanbul: İSAR Yayınları, 2017.

Hareş, Abdurrahman Rıdvan. "Menhecu İbn Kemâl Bâşâ rahimehullah fî resâilihî fi tefsîri suverin mahșûșạ, el-mațbû'a minhâ ve'l-mahțûța". Osmanlı Döneminde Tefsir. ed. Hidayet Aydar vd. 1/107-129. İstanbul: Ensar Neşriyat, 2018.

Hirmâs, Abdürrezzak b. İsmail. "Menhecu Ahmed b. Kemâl (940 h.) fî tefsîri âyâti'l-aḥkâmi sûreti'l-Baḳara enmûzecen". Osmanlı Döneminde Tefsir. ed. Hidayet Aydar vd. 1/71-104. İstanbul: Ensar Neşriyat, 2018.

el-Bekrî, Hamza. “'el-Erba'înât' el-ḥadîsiyye fi'l-ḳarni'l-'âşir el-hicrî min İbn Kemâl Bâşâ ile'l-Birgivî, dirâse naḳdiyye muḳârene". Balıkesirli Bir İslam Âlimi İmam Birgivi. ed. Mehmet Bayyiğit vd. 2/567-594. Balıkesir: Balıkesir Büyükşehir Belediyesi Kültür Yayınları, 2019. 


\section{Diğer Yabancı Dillerdeki Çalışmalar}

Kemalpaşazade, İbn Kemal Ahmed Şemseddin. "Berteri-yi Zebân-i Pârsî ber Dîger Zebânhâ (Risâle-i Berteri-yi Zebân-i Pârsî ber Zebânhâ-yi Dîger becoz Arabî)". çev. Pervîz Ezkâyî. Edebiyyât ve Zebânhâ 66 (1348), 494-502.

Ménage, V. L. “MS Fatih 4205: An Autograph of Kemālpashazāde's Tevārīknh-i Āl-i 'Othnmān, Book VII". Bulletin of the School of Oriental and African Studies, University of London 23/2 (1960), 250-264.

Uğur, Ahmet. The Reign of Sultān Selìm I in The Light of The Selìm-nāme Literature. Edinburhg: University of Edinburgh, Doktora Tezi, 1973.

Grignaschi, Mario. "La Condanna Dell 'Apostasia (Irtitâd) Sciita Nella "Risâlah" Di Ibn Kemâl A Selim I”. Oriente Moderno 3/64 (1984), 57-63.

Uğur, Ahmet. The Reign of Sultan Selìm I in The Light of The Selìm-nāme Literature. Berlin: Klaus Schwarz Verlag, 1985.

Lukač, Ušanka Bojanić. “Two Years in the History of the Bosnian Regions (1479 and 1480) - According to Ibn Kemal". Prilozi za Orijentalnu Filologiju 36 (1987), 313-331.

Winter, Tim. "Ibn Kemāl (d. 940/1534) on Ibn 'Arabī's Hagiology". In Sufism and Theology. ed. Ayman Shihadeh. 137-157. Edinburgh: Edinburgh University Press, 2007.

Kemalpaşazâde. "Risâletu'l-İhtilâf beyne'l-Eşâ'ira ve'l-Mâturîdiyye fî İsnetey 'Aşrate Mes'ele". Sunnitische Theologie in Osmanischer Zeit. ed. Edward Badeen. 20-23. Würzburg: Ergon Verlag, 2008.

Pienaru, Nagy - Cristea, Ovidiu. “Campania Otomană din 1484. Mărturia lui Ibn Kemal (The Ottoman Campaign in Moldavia (1484). Ibn Kemal's Testimony)". Analele Putnei 1 (2012), 43-58.

Schmidt, Jan. "The importance of Persian for Ottoman literary gentlemen: two Turkish treatises on aspects of the language by Kemal Pashazade (d. 1536)". Kitaplara Vakfedilen Bir Ömre Tuhfe: İsmail E. Erünsal'a Armağan. ed. Hatice Aynur vd. 2/851-865. İstanbul: Ülke Yayınları, 2014.

al-Tikriti, Nabil. "İbn Kemal's Confessionalism and the Construction of an Ottoman Islam". Living in the Ottoman Realm: Empire and Identity, 13th to 20th Centuries. ed. Christine Isom Verhaaren - Kent F. Schull. 95-107. Bloomington: Indiana University Press, 2016.

Şen, A. Tunç. “Practicing Astral Magic in Sixteenth-Century Ottoman Istanbul: A Treatise on Talismans Attributed to Ibn Kemāl (d. 1534)". Magic, Ritual and Witchcraft 12/1 (2017), 66-88. 


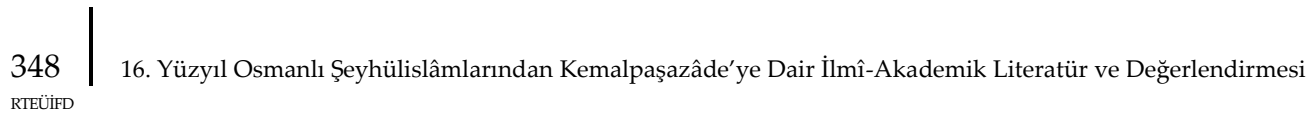

Ansari, Rosabel P. "Ibn Kemal, Dawān̄̄ and the Avicennan Lineage". Mélanges de l'université Saint Joseph 67 (2018), 237-264.

Drkić, Munir - Zildžić Ahmed. “Traktat O Značenju Riječi Zındīq (Treatise On The Meaning Of The Term Zındīq)" Prilozi za Orijentalnu Filologiju 68 (2019), 1-25.

Sezer, Hatice. "A Sixteenth Century Intellectual And Statesman: Kemalpaşazade". Tarih Araştırmaları Dergisi 39/67 (2020): 215-235.

Hatipler, Mustafa. "One Person Library from Law and Morality to Social Policy: Muallim-i Evvel İbni Kemâlpaşazâde”. Journal of Balkan Libraries Union 8/1 (2021), 14-22.

Kirakosyan, Hasmik - Sargsyan, Ani. "On the Appropriation of Lexicographic Methods of Kemālpaşazāde's (1468-1534) Glossary Daḳāyiḳu 1-ḥaḳāyiḳ”. Diyâr 2/1 (2021), 14-26.

\section{SONUÇ}

Kemalpaşazâde hem siyasi hem de ilmî anlamda döneminin güçlü simalarından biridir. Ona bu otoriteyi kazandıran, ömrünün sonlarında ifâ ettiği şeyhülislâmlık vazifesi ve kaleme aldığı yüzü aşkın eseridir. Kemalpaşazâde'nin tarihî ve ilmî önemi, yaşadığı döneme damga vurmasını ve dolayısıyla günümüzde ilmî çalışmalara konu edinmesini sağlamıştır. Bu konu edinme çok farklı boyutlarda gerçekleşmiştir. Zira Kemalpaşazâde Türkçe, Arapça ve Farsça dillerinde farklı alanlara dair eser ve risaleler telif ederek kendini ne tek bir alanla ne de tek bir dille sınırlamıştır. Eserlerinden hareketle o, hem bir filozof, hem bir kelâmcı, hem bir tarihçi, hem bir tefsirci, hem bir dilci, hem bir fakih ve hem de bir şairdir. Günümüzde Kemalpaşazâde'yi bu denli çok çalışılmış bir isim kılan unsurların başında da onun bu çok yönlü kişiliği ile velüt bir âlim olması gelmektedir.

Literatür değerlendirilirken, çalışmaların oranlarını gösteren bir grafik ve dağılımlarını gösteren bir tablo kullanımı tercih edilmiştir. Kullanılan grafik ve tablodaki değerler ise yalnızca bu makaledekilerle sınırlı tutulmamıştır. Başka bir deyişle söz konusu grafik ve tablo, hem Demir ve Çatılı'daki hem de bu makaledeki çıtılar esas alınarak oluşturulmuştur. Hazırlanan grafik, yapılmış tüm çalışmaları; tez, kitap, makale, tebliğ ve ansiklopedi maddeleri olmak üzere türlerine göre ayırmakta ve toplam çalışma sayısını içermektedir. Bununla birlikte türlerin toplam sayıya oranları da istatistiksel bir değer ifade etmesi sebebiyle ayrıca belirtilmiştir. 


\section{Grafik 1: Çalışmaların Türlerine Göre Grafiği}

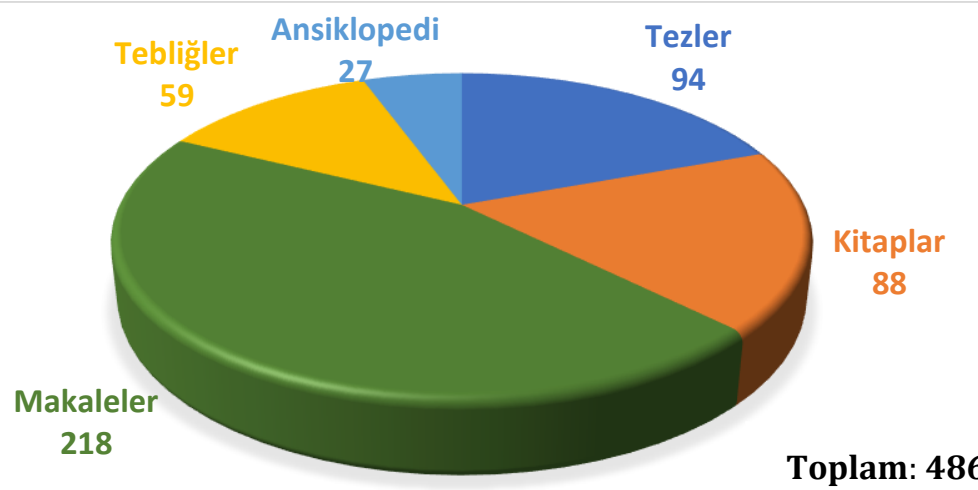

Tüm çalışmalara nispetle; makalelerin oranı: $\% 45$, tezlerin oranı: $\% 19$, kitapların oranı: \%18, tebliğlerin oranı: \%12 ve ansiklopedilerin oranı: \%6.

Tablo 1: Çalışmaların Dillere, Türlere ve Alanlara Dağılımını Gösteren Tablo

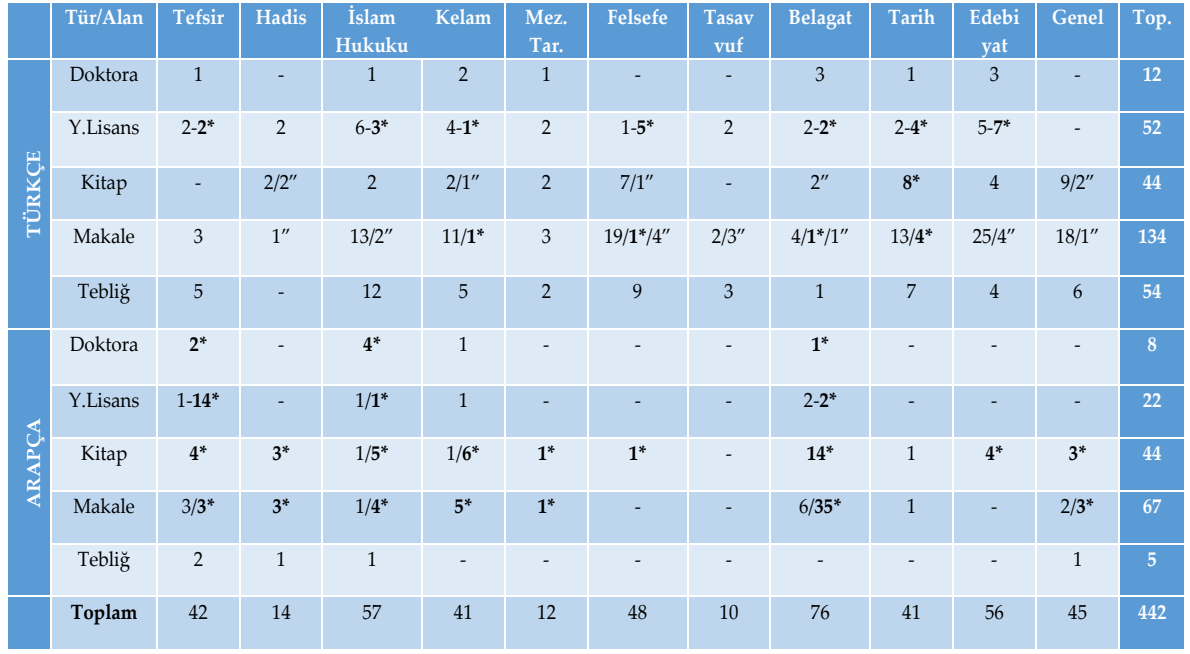

Yukarıdaki tabloda Kemalpaşazâde'ye dair yapılan çalışmalar ilk sütunla dillerine ayrılmaktadır. Diğer yabancı dillerdeki çalışmalar sayıca yeterli olmadıkları için grafiğe dâhil edilmemiştir. Türkçe ve Arapça olarak hazırlanan eserler ikinci sütunla doktora, yüksek lisans, kitap, makale ve tebliğ olarak beşe ayrılmıştır. Burada da belirli bir alana girmediği için ansiklopedi maddeleri dışarıda bırakılmıştır. Sondaki sütun ise bu türlerde kaleme alınan toplam çalışma sayısını ifade etmektedir. Son olarak tablodaki en üst satır, çalışmaların hangi bilimsel disiplinde hazırlandığını; en alt satır da bu disiplinlerdeki toplam çalışma miktarını göstermektedir. 


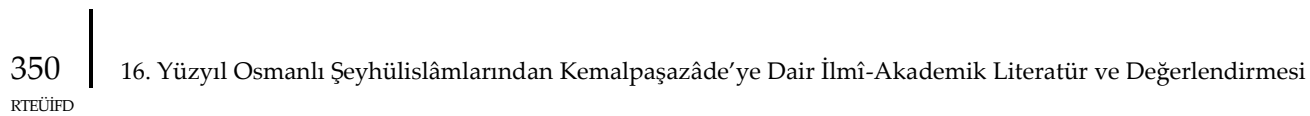

Çalışmalar, hazırlandıkları bilim dalları esas alınarak sınıflandııılmıştır. Buna karşın herhangi bir disipline ait olmayan eserler, "Genel" şeklinde ayrı bir bölüm açma zorunluluğu doğurmuştur. Bu kısımda Kemalpaşazâde'nin hayatı ve eserleri hakkında genel bilgi veren yayınlar, eserlerine dair bibliyografik metinler, toplu tahkik çalışmaları ve terimler sözlüğü yer almaktadır. Tabloya ilişkin değinilmesi gereken son iki husus ise yıldız ve tırnak işaretleridir. Tablodaki yıldız işaretleri ${ }^{*}$ ) tahkik çalışmalarını ifade etmek için kullanılmıştır. (Yıldız işareti kitaplar söz konusu olduğunda neşirlerleri de belirtmektedir.) Tırnak işaretleri ise (") tercüme çalışmalarını göstermektedir.

Türkçe literatür incelendiğinde doktora tezlerinin belirli bir alanda yoğunlaşmayıp çeşitli bilim dallarına yayıldıkları görülmektedir. Çalışmaların geniş bir perspektife dağılmasının nedeni de zikredildiği üzere Kemalpaşazâde'nin neredeyse her alana dair gerek kitap gerek risale türü teliflerinin bulunmasıdır. Tezlerin yıllara göre dağılımları söz konusu olduğunda genellikle geçmiş dönemde yapıldıkları; yakın zamanda tamamlanmış bir doktora çalışmasının bulunmadı̆̆ görülmektedir. Zira Kemalpaşazâde'ye ilişkin en son doktora tezi 2010 yılında tamamlanmıştır. Yüksek lisans düzeyinde ise tespit edilen 52 tezin yaklaşık yarısı (24) tahkik çalışmasıdır. Yapılan tezlerden hareketle görülmektedir ki Kemalpaşazâde yüksek lisans düzeyinde hala çalışılmaya devam eden canlı bir konu olarak yerini korumaktadır. Nitekim son beş yılda Kemalpaşazâde üzerine toplam on sekiz yüksek lisans tezi tamamlanmış olup yeni tezler de yazılmaya devam etmektedir.

Kemalpaşazâde'ye ilişkin yazılan kitapların (44) bir kısmını yayımlanmış doktora tezleri bir kısmını Kemalpaşazâde'yi genel hatlarıyla tanıtan küçük hacimli kitaplar oluşturmaktadır. Kalanlar ise felsefe ve tarih alanlarına yoğunlaşmıştır. Bu noktada dikkat çeken husus, tarih alanındaki tüm kitapların neşir veya tahkik hüviyetinde oluşudur. Bunun sebebi, Kemalpaşazâde'nin on ciltlik bir tarih eseri kaleme almış olması ve çeşitli araştırmacıların bu eseri cilt cilt -veya metnin aslına uygun olarak defter defter- yayımlamalarıdır. Kemalpaşazâde'nin on cilt olan bu tarih kitabının beşinci cildinin kayıp olduğu ve hiçbir nüshasına ulaşılamadığı burada belirtilebilir. Ayrıca farklı araştırmacılar tarafından neşredilen ve dağınık halde bulunan söz konusu çalışmaların tek bir yayınevi tarafından gözden geçirilerek tekrar seri halinde yayımlanması gerektiğine de işaret edilmelidir. Makalelere gelindiğinde, Arapça makalelerde yoğunluk tefsir ve belağat alanlarındayken Türk akademisinde neredeyse en az yoğunluk -makale özelinde- bu alanlarda olmuştur.

Tebliğler söz konusu olduğunda bunların bir kısmı Kemalpaşazâde için tertip edilen sempozyumda, bir kısmı da Tokatlı bir âlim olması hasebiyle Tokat iline dair düzenlenen sempozyumlarda sunulmuş metinlerdir. Bu sempozyumların ilki 1985 yılında Tokat şehrinde "Şeyhülislam İbn Kemâl Sempozyumu" başlığıyla 
gerçekleşmiştir. Mezkûr sempozyumda yirmi bir tebliğ sunulmuştur. Türkçe toplam tebliğ sayısı düşünüldüğünde (54) bunun takribî yarısının bu sempozyumda üretildiği görülmektedir. Bununla beraber sempozyum vesilesiyle Kemalpaşazâde üzerine yapılan çalışmalarda büyük bir yükseliş olmuştur. Söz gelimi 1985 yılına kadar tespit edilen toplam çalışma sayısının (42) yarısı sırf bu sempozyumda üretilmiştir. Yayımlanan tebliğlerin -muhtemelen henüz bir birikim oluşmadığı içinyüzeysel kaldığ1 söylenebilse de sempozyumların belirli bir konuya ilginin oluşturulması ve konunun çeşitli yönlerden çalışılmasını sağlaması bakımından önemli olduğu görülmektedir.

Neşir ve tahkik çalışmalarına gelince, bir âlimin eserlerinin tahkik edilmesi, araştırmacıları o ismi anlamaya bir adım daha yaklaştırmaktadır. Bu meyanda Kemalpaşazâde'nin eserlerine yapılan neşir ve tahkik çalışmaları onu anlama noktasında önem kazanmaktadır. Dikkate değer bir isim olması sebebiyle Kemalpaşazâde'ye dair neşir çalışmaları çok erken tarihlerde başlamıştır. Söz gelimi ona dair tespit edilen ilk neşir çalışması 1848 tarihlidir. Bunun yanında 1900'lü yıllara kadar on iki eseri tahkike yahut neşre konu olmuştur. Bunlardan en meşhur olanı Ahmet Cevdet tarafından hazırlanan Resâil-i İbn Kemâl'dir. Nitekim o, Kemalpaşazâde'nin 36 risalesini iki cilt halinde 19. yüzyılın sonunda neşretmiş ve okuyucuların istifadesine sunmuştur. Neşir ve tahkik çalışmalarının önemi Ahmet Cevdet'in eseri üzerinden rahatlıkla incelenebilir. Eserdeki hadis şerhine (Salih Özer), mucizenin hakikatine (H. İ.Bulut; Recep Demir), içkinin haramlığına (Ö. F. Habergetiren) ve Farsçanın faziletine (İsmail Bayer) dair risaleleri merkeze alan makale çalışmaları yapılmıştır. Bu itibarla zikri geçen makalelerin ortaya çıkmasını sağlaması yönüyle neşir ve tahkik çalışmalarının, gelecekteki çalışmalara önayak olduğu zikredilebilir. Literatürde Kemalpaşazâde üzerine yapılan tahkik çalışmalarının yeni araştırmaların önünü açtığına dair daha pek çok örnek bulunmaktadır.

Arapça literatür göz önüne alındığında doktora seviyesinde sekiz tez tamamlandığı, bunların da yedisinin tahkik çalışması olduğu görülmektedir. Tahkik olmayan tek çalışma da risalelerinden hareketle Kemalpaşazâde'nin kelâmî görüşlerini sistematik bir biçimde okuyucuya sunmaya çalışan Seyit Bahçivan'a aittir. İleride de görüleceği üzere Arapça çalışmaların büyük kısmı tahkik konusuna yoğunlaşmıştır. Yüksek lisans düzeyindeki 22 tezin de 17 tanesi Kemalpaşazâde'nin risâle veya eserlerinin tahkikini içermektedir. Yüksek lisans tezleri özelinde tefsir, en çok çalışmanın bulunduğu ilim dalıdır. Tefsir alanındaki tez sayısı 15 olup araştırmacılar sure sure risaleleri tahkik etmişlerdir. Türkiye'den farklı olarak Arapça literatürde tezlerin 90’lı yıllarda yoğunlaştı̆̆ı görülmektedir. Söz gelimi Kemalpaşazâde -zikredildiği üzere- Türkiye'de yüksek lisans aşamasında canlılığını korumaya devam ederken geçmiş on yıl içerisinde -tespit edildiği kadarıyla- Arapça 
352 16. Yüzyıl Osmanlı Şeyhülislâmlarından Kemalpaşazâde'ye Dair İlmî-Akademik Literatür ve Değerlendirmesi RTEÜIFD

kaleme alınmış iki tane tez bulunmaktadır. Kaldı ki bunlardan biri de Yalova'da tamamlanmıştır. Bu itibarla Arapça tezler söz konusu olduğunda Kemalpaşazâde'ye olan ilginin azaldığı gözlemlenmektedir. Makaleler özelinde de 54'ü tahkik çalışması olan 67 makalenin 41'ini belâgat alanındaki yayınlar teşkil etmektedir. Buradan hareketle belâgat alanındaki yoğunluğun Arap araştırmacıların Arapça diline dair ilgisinden kaynaklandığı ve bu bağlamda Kemalpaşazâde'nin risalelerini öne çıkardıkları düşünülebilir.

Ortaya çıkan literatürde en az çalışılan alanlar hadis ve tasavvuf olmuştur. Hadis ilmi özelinde bu durumun nedeni, müellifin hadis ilmine dair müstakil risalelerinin sayısının az olmasıdır. Zira Kemalpaşazâde bazı hadislerin şerhi ve kırk hadis çalışması dışında hadis alanına kayda değer pek fazla katkıda bulunmamıştır. Yapılan çalışmalar da genellikle onun kırk hadis risalelerini merkeze alarak oluşturulmuştur. Tasavvuf alanındaki araştırmalar da onun sûfî gruplar ve İbn Arabî’ye dair verdiği fetvalarından hareketle inşa edilmiştir. Arap araştırmacıların tasavvuf alanında hiç çalışmaları olmadığı gibi 41 tarih çalışmasından da yalnızca iki tanesi onlara aittir. Tevârîh-i Âl-i Osman, Osmanlı tarihini anlattığı için araştırmacıların ilgisini çekmemiş olabilir.

Eldeki bulgulardan hareketle genel bir değerlendirme yapmak gerekirse, Kemalpaşazâde üzerine yapılan çalışmaların zamanla evrildikleri yön şu şekildedir: Genellikle ilk çalışmalar Kemalpaşazâde'nin biyografisini içeren kısa metinler olmuştur. Ayrıca Kemalpaşazâde'nin eser ve risalelerini tespit amacıyla da pek çok çalışma yapılmıştır. Nihat Atsız, müellifin eserlerini kütüphane kataloglarıyla birlikte yayımlamıştır. Bunun yanına Cemil el-Azm 1326/1908' de Beyrut'ta basılan 'Ukûdü'lcevher adlı eserinde Kemalpaşazâde'ye ait risaleleri sıralamıştır. Bu çerçevede tahkik ve neşir haricinde yapılan ilk çalışmalar, genellikle küçük hacimli onu tanıtıcı nitelikte ve eserlerini tespite yönelik olmuştur. Akabinde araştırmalar eserlerinin tahkikine yönelmiştir. Bu durum özellikle yüksek lisans çalışmalarında görülmektedir. Burada öncesinde tahkik edilen çalışmaların yeniden tahkik edilmesine de sıklıkla rastlanmaktadır. Söz gelimi Kemalpaşazâde'nin Dekâyı ku'l-hakâayık adlı eseri farklı zamanlarda üç kere çalışılmıştır. Sonrasında araştırmalar, tahkik edilen metinler üzerine yapılmaya başlanmış ve devamında da karşılaştırmalı çalışmalarla devam etmiştir. Ancak araştırmaların zamanla evrildikleri yön bağlamında zikredilen bu süreç bir genelleme olup kesin bir iddia taşımamaktadır. Zira Kemalpaşazâde'nin eserleri her zaman için tahkik edilmeye devam etmiştir ve etmektedir.

İncelendiği üzere tahkik ve tercümeler yeni ve dakik çalışmalara vesile olmaları itibariyle değerli olmakla birlikte boş bir çabaya da dönüşmemeleri gerekmektedir. Zira hem Türk hem de Arap araştırmacılar aynı eserleri tahkik ve tercüme etme hatasına düşmüşlerdir. Bu durumun önlenmesi günümüz şartlarında kolaylıkla 
aşılabilecek bir engeldir aslında. Söz gelimi İSAM veya herhangi bir site bünyesinde açılacak bir veritabanı üzerinden araştırmacılar tahkik veya tercüme ettikleri/edecekleri eserleri girseler ve gidişata göre güncelleseler tekrara düşen çalışmalar büyük ölçüde azalır ve alanda yapılan çalışmalar noktasında haberleşme imkânı artmış olur.

Son tahlilde literatür incelendiğinde Arapça çalışmaların tefsir ve belâgat ilimlerinde yoğunlaştığı görülmektedir. Söz konusu çalışmaların çoğunluğunu da tahkik çalışmaları oluşturmaktadır. Bununla birlikte Türkçe literatürde edebiyat, tarih, felsefe, İslam hukuku gibi alanlarda da pek çok çalışmanın yapıldığ arası daha eşit bir dağılımın bulunduğu gözlemlenmektedir. Literatürdeki çalışmaların her birinin aynı nitelikte olmadığı kabul edilmekle beraber Kemalpaşazâde gibi- her bir Osmanlı âlimi için bu kadar belki daha fazla çalışma yapılmalıdır ki İslâm düşünce geleneğinin "kopuk halkası” olan Osmanlı dönemi de bir nebze olsun aydınlatılabilsin ve tevârüs eden ilmî birikim kesintisiz bir biçimde günümüze kadar getirilebilsin. 
\begin{tabular}{l|l}
354 & 16. Yüzyıl Osmanlı Şeyhülislâmlarından Kemalpaşazâde'ye Dair İlmî-Akademik Literatür ve Değerlendirmesi \\
RTEÜIFD &
\end{tabular}

\section{KAYNAKÇA}

Alak, Musa. Kemalpaşazâde'nin Şerhu Tağyîri'l-Miftâh Adlı Eserinin Tahkik ve Tahlili. İstanbul: Marmara Üniversitesi, Sosyal Bilimler Enstitüsü, Doktora Tezi, 2009.

Atsız, Nihal. “Kemalpaşa-Oğlu'nun Eserleri”. Şarkiyat Mecmuası 6 (1966), 71-112.

Atsız, Nihal. “Kemalpaşa-Oğlu'nun Eserleri”. Şarkiyat Mecmuası 7 (1972), 83-135.

Demir, Halis - Çatılı, Kemal. "İbn Kemal Üzerine Yapılan İlmi Çalışmalar”. Tokat Gaziosmanpaşa Üniversitesi İlahiyat Fakültesi 7/1 (2019), 151-178.

Kemalpaşazâde, Ahmed Şemseddin. Mecmû'u resâili'l-'allâme İbn Kemâl Bâşâa. thk. Hamza el-Bekrî vd. İstanbul: Dârü'l-Lübâb, 2018.

Öçal, Şamil. Kemal Paşazâde'nin Felsefi ve Kelâmî Görüşleri. Ankara: Ankara Üniversitesi, Sosyal Bilimler Enstitüsü, Doktora Tezi, 1998.

Saraç, M. Yekta. Şeyhülislam Kemal Paşazâde: Hayatı, Şahsiyet, ve Bazı Şiirleri. İstanbul: Risale Yayınları, 1995.

Sarıkaya, Muammer. Kemal Paşa-zâde'nin Yabancı Kelimelerin Arapçalaştırılması ve Dil Hataları Konusunda İzlediği Yöntem. İstanbul: İstanbul Üniversitesi, Sosyal Bilimler Enstitüsü, Doktora Tezi, 2004. 